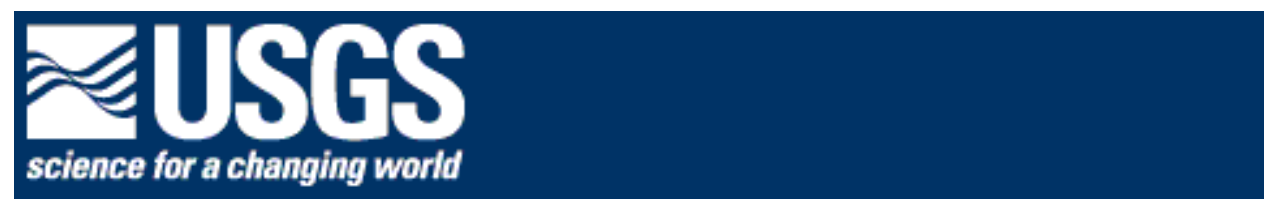

\title{
The Cretaceous-Tertiary Boundary Interval in Badlands National Park, South Dakota
}

\author{
Philip W. Stoffer ${ }^{1}$ \\ Paula Messina \\ John A. Chamberlain, Jr. \\ Dennis O. Terry, Jr.
}

U.S. Geological Survey Open-File Report 01-56

2001

U.S. DEPARTMENT OF THE INTERIOR

Gale A. Norton, Secretary

U.S. GEOLOGICAL SURVEY

Charles G. Groat, Director

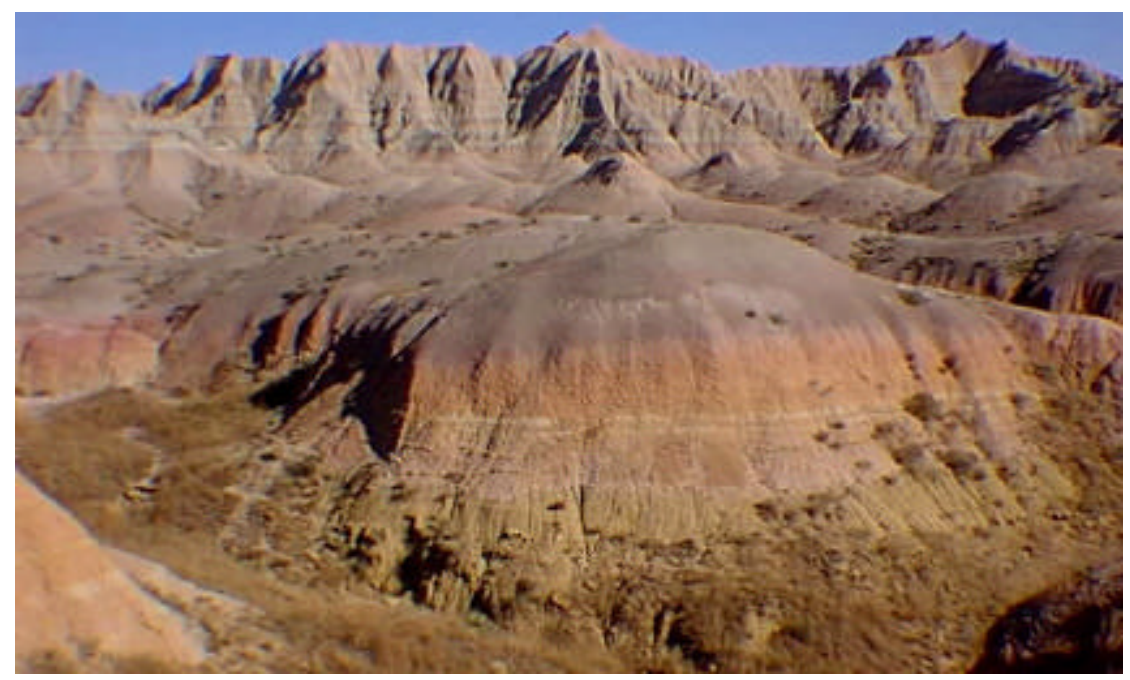

The Cretaceous/Tertiary (K-T) boundary study interval at the Rainbow Colors Overlook along Badlands Loop Road, North Unit of Badlands National Park.

This report is preliminary and has not been reviewed for conformity with U.S. Geological Survey (USGS) editorial standards or with the North American Stratigraphic Code. Any use of trade, firm, or product names is for descriptive purposes only and does not imply endorsement by the U.S. Government.

${ }^{1} 345$ Middlefield Road, Menlo Park, CA 94025

http://geopubs.wr.usgs.gov/open-file/of01-056/ 


\section{ABSTRACT}

A marine K-T boundary interval has been identified throughout the Badlands National Park region of South Dakota. Data from marine sediments suggest that deposits from two asteroid impacts (one close, one far away) may be preserved in the Badlands. These impactgenerated deposits may represent late Maestrichtian events or possibly the terminal K-T event. Interpretation is supported by paleontological correlation, sequence stratigraphy, magnetostratigraphy, and strontium isotope geochronology. This research is founded on nearly a decade of NPS approved field work in Badlands National Park and a foundation of previously published data and interpretations.

The K-T boundary occurs within or near the base of a stratigraphic interval referred to as the "Interior Zone." We interpret the stratigraphy of the Interior Zone as a series of distinct, recognizable lithologic members and units from oldest to youngest, an upper weathered interval of the Elk Butte Member of the Pierre Shale (early late Maestrichtian), a complete (albeit condensed) interval of Fox Hill Formation, a pedogenically altered K-T Boundary "Disturbed Zone," and a generally unresolved sequence of marine to marginal marine units ranging in age from possibly latest Maestrichtian to late Paleocene (the "Yellow Mounds"), that underlie a basal red clay unit (the late Eocene overbank channel facies of the Chamberlain Pass Formation at the base of the White River Group). Within this sequence is a series of unconformities that all display some degree of subaerial weathering and erosion. The dating of marine fossils above and below these unconformities are in line with generally accepted global sea-level changes recognized for the late Campanian through early Eocene. Within the greater framework of regional geology, these findings support that the Western Interior Seaway and subsequent Cannonball Seaway were dependently linked to the changing base-level controlled by sea-level of the global ocean through the Gulf of Mexico and possibly the Arctic Ocean. The variation of facies preserved in Late Cretaceous strata in the Badlands National Park area were in part controlled by local or regional tectonic blocks that were either rising or sinking contemporaneous with deposition.

\section{ACKNOWLEDGMENTS}

Many people deserve acknowledgment for their assistance and guidance in this research. Foremost is Rachel Benton, paleontologist of Badlands National Park. The park administration and staff have been extremely supportive of our ongoing research. The majority of our previous funding came from the State of New York via several CUNY Research Foundation grants, a U.S. Geological Survey (USGS) EDMAP grant, and an AMNH Lerner/Grey grant. Field assistance and identification of fossils was provided by Neil Landman (AMNH), William A. Cobban (USGS), and Gorden Bell (NPS). Thermal-scan paleomagnetic determinations were conducted by Duane Champion (USGS). Scanning electron microscope methods and photography services were provided by Robert Oscarson (USGS). Other individuals how have contributed field assistance include Martin Becker, Lew Factor, Patricia Sannett, Jerry Mundt, and Doreen Patrick. 


\section{INTRODUCTION}

Our previous investigations have focused on gross correlation and interpretation of the entire Late Cretaceous section exposed in Badlands National Park (Stoffer, 1998; Stoffer and others, 1998, Stoffer and others, 1996). Our data suggest that a near complete Late Cretaceous (late Campanian-Maestrichtian) section is preserved in Badlands National Park, although it is somewhat condensed in comparison to other locations in the Western Interior region. Resolution of the Cretaceous/Tertiary (K-T) boundary in the Badlands is founded on field and laboratory observations to resolve regional correlation issues of the Pierre Shale and Fox Hills Formations throughout the Western Interior region of South Dakota and eastern Wyoming (Stoffer and others, 2000; Stoffer and others, 1999; Stoffer, 1998) (fig. 1). Resolution of the park stratigraphy began in the lower more fossiliferous zones exposed along Sage Creek and proceeded up-section into the more unresolved upper part of the section. To this end, ammonite biozonation and lithologic characteristics demonstrate that the park's stratigraphy is generally consistent with the upper Pierre Shale and Fox Hills in the type areas originally described in the Missouri River Valley (Searight, 1937; Crandall, 1958, Landman and Waage, 1993) and along the western flank of the Black Hills (Gill and Cobban, 1966) (fig. 2). Highlights of these investigations included the discovery of an unconformity encompassing the Campanian-Maestrichtian boundary interval in the Badlands region, and additional hiatuses higher in the section. Early in our investigations we concluded that local tectonism (such as uplift of the Sage Creek Arch and the more distant Black Hills region) controlled the distribution and character of sediments deposited in latest Campanian and throughout the Maestrichtian (fig. 3). In general, units thicken in synclinal areas and thin or pinch out across structural highs. On a regional scale, Cretaceous units gradually dip and thicken eastward across the park away from the Black Hills and continue to thicken toward the Missouri River valley. North of the Sage Creek Arch, the strata also thicken northward toward the Williston Basin.

\section{The Yellow Mounds/Fox Hills "Problem"}

Resolving the K-T boundary section has not been easy, and much work still needs to be done. Perhaps the greatest hindrance is the general lack of fossils preserved in the upper part of this historically enigmatic section. In the historic literature, the section has been referred to by such names as the "Rusty Beds," "Interior Formation," "Interior Zone," among others (Agnew and Tychsen, 1965). Using fig. 2, the interval in question is most easily defined as the strata between the top of the "gray Pierre Shale" and the base of the Chadron Formation. The phrase "gray Pierre Shale" is used loosely because the age of the top of the "gray" varies widely from early to late Maestrichtian in age. Ward $(1922,1924)$ first suggested that the sandy facies and glauconitic greensands within the "Interior Formation" in the Badlands was equivalent to the Fox Hills Fm., but this interpretation was somewhat rebuffed by competing hypotheses suggesting that the colorful pre-Chadron sequence represented a deep weathering profile on older strata of the Pierre Shale. This later interpretation has been an ongoing paradigm of sorts, supported by comments in publications by Pettyjohn $(1966,1967)$ and by Raymond and King (1976). Pettyjohn (1966) first used the locally popular name "Yellow Mounds" to apply to the section. Pettyjohn (1966), Retallack (1983), and Terry and Evans (1994) resolved Tertiary weathering profiles (paleosols) established on or above an eroded surface of the Cretaceous Pierre Shale and locally on the Fox Hills. 


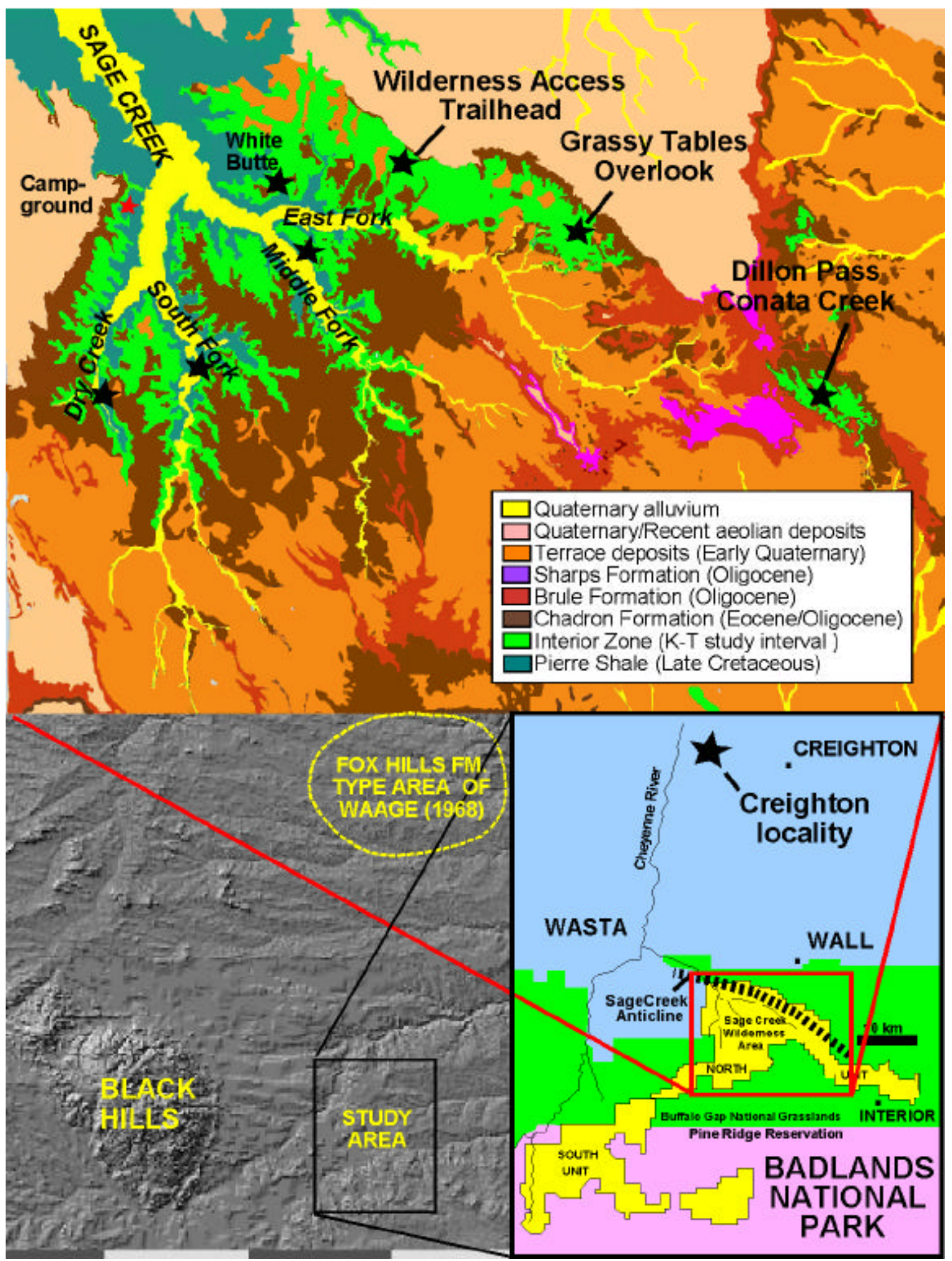

Figure 1. Study area (stars indicate field localities mentioned in text). 


\section{BADLANDS NATIONAL PARK Pre-White River Stratigraphy}

Rock Unit Names

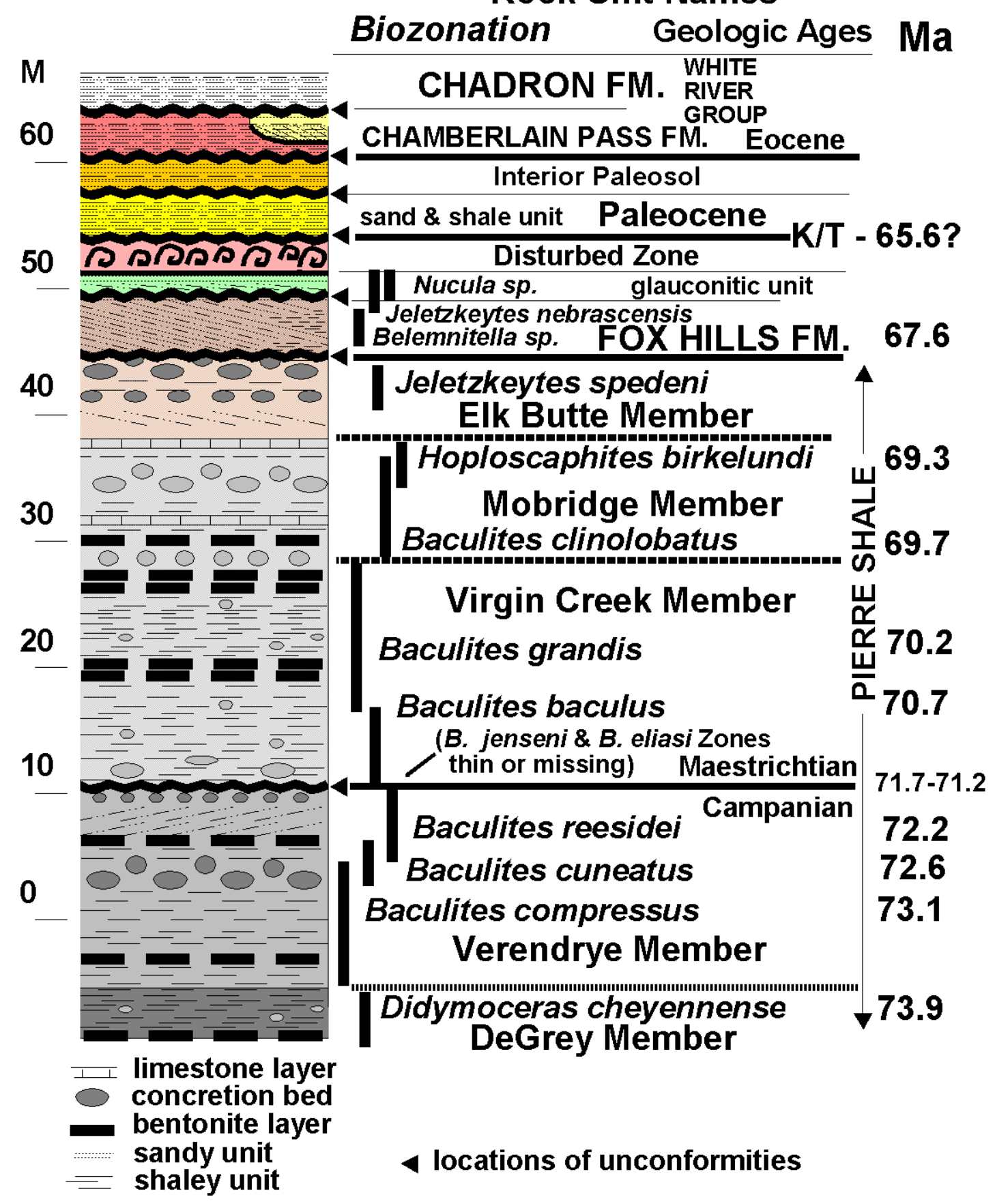

Figure 2. Composite columnar section showing pre-White River Group stratigraphy. 


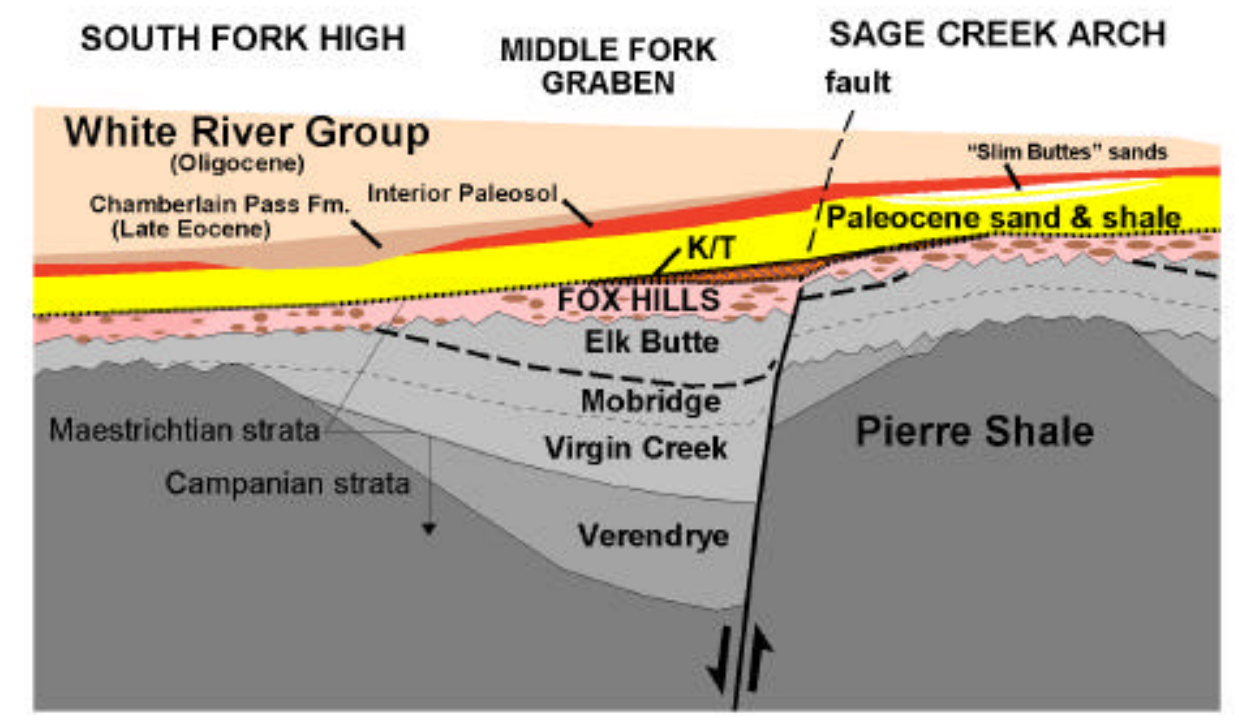

Figure 3. Generalized north-south cross section through the Sage Creek Wilderness Area of Badlands National Park, North Unit, showing an interpretation of surface and subsurface stratigraphy in relation to structural features.

Retallack (1983) showed the possibility that sedimentary features in this pre-Chadron section could best be interpreted as two paleosol horizons. He called a lower weathering profile on an irregular surface cutting through the Pierre Shale and Fox Hills Formations the "Yellow Mounds Paleosol Series." He interpreted an upper weathering profile (named the "Interior red clay" or "Interior Paleosol Series") as a late Eocene paleosol imprinted, in part, on the older strata. Retallack (1983) concurred with observations previously made by Clark and others (1967), who noted lithologic similarities between the sandy layers beneath the Interior Red Clay and the Eocene Slim Buttes Formation of northwestern South Dakota. Evans and Terry (1984) later combined the white channel sandstone and red mudstone of the Interior Paleosol Series into a single unit, the late Eocene Chamberlain Pass Formation. In this light, Retallack (1983) was the first to postulate that the K-T boundary was below the base of the Chadron Formation. However, these previous interpretations suggest that the Pre-Chadron K-T boundary represented a major unconformity - representing an extended period of weathering and erosion having removed latest Cretaceous and Paleocene sediments.

Our interpretations differ from those of previous researchers in that we believe the Badlands' section shows significant evidence to support interpretation of ongoing sediment deposition concurrent with regional and local uplift as far back as the late Campanian and up through the mid-late Oligocene. Using a sequence-stratigraphy model for the shallow Western Interior Seaway, we contend that in tectonic high areas, such as along the Sage Creek Arch in the North Unit of Badlands National Park, only the marine highstand systems tracts are preserved, whereas non-deposition, erosion, and subaerial exposure prevailed on tectonic high areas when sea-level fell. In topographic high areas, lowstand system tracts are preserved as unconformities 
that locally preserve subaerial weathering profiles (paleosols). In adjacent low spots, sediments bearing reworked fossils and concretions were redeposited in locally prograding, clinoform-style submarine mudbanks (Stoffer, 1998) and as low, silty mud shoal on the bottom of the seaway. As a result, the early tectonic history of the Laramide Orogeny in the greater Badlands region may be resolved by closer scrutiny of the Late Cretaceous marine facies. Our observations suggest that uplift of the Black Hills, the Sage Creek Arch, the Chadron Arch, and other local and regional structures influenced sedimentation patterns of the Pierre Shale and Fox Hills Formations east of the Black Hills. The Late Cretaceous Sheridan Delta (Gill and Cobban, 1973) may have provided sediments to the Badlands area and affected the shoreline geometry in the region, but the major distributary channel sands of the Fox Hills and Hell Creek of northwestern South Dakota never migrated as far south as the park. Uplifts such as the Sage Creek Arch and other anticlines to the north and west probably prevented the migration of Sheridan Delta distributary facies directly into the Badlands National Park area.

Our recent investigations resulted in discoveries that shed additional insight into character of the "Interior Zone" (the unresolved interval spanning the K-T boundary). Of perhaps greatest significance was recognition of a widespread interval of soft-sediment deformation. Preliminary data suggest that this event horizon may have formed synchronous with the K-T boundary. This stratigraphic unit is referred to in this report as the "Disturbed Zone " (DZ). Previously, we interpreted this unit to represent buried slumps that formed in the uppermost Pierre Shale (Stoffer, Messina, and Chamberlain, 1997). Perhaps hampered by caution and skepticism, we tempered our interpretations that the "slump zone" developed on a southward prograding mudbank that had formed along the south flank of the rising Sage Creek Anticline. However, information derived from additional field reconnaissance demonstrated that this unit was too widespread to represent slumping. Data now show that strata in Badlands National Park locally host a nearly complete Fox Hills section. Comparison with the Missouri River Valley Type Fox Hills of Waage (1968) suggests that the Badlands section is equivalent to the Trail City, Timber Lake, and Colgate members. Further work is necessary to resolve correlation of the Badlands section to equivalent marine and terrestrial facies of the Hell Creek in northwestern South Dakota.

\section{DISCUSSION}

The following discussion outlines our evidence for a dominantly marine K-T boundary section in Badlands National Park. We feel it is important to emphasize that field observations are the most important component to this research. Interpretation is an ongoing progression of paradigm construction and destruction partly moderated by past and recent published literature. The paradigm presented here would not have evolved without the advances in modern sequence stratigraphy or the progress of the asteroid impact theories associated with the K-T Boundary. Our data presented strongly suggest that strata preserved in Badlands preserve evidence of sedimentary features attributable to distant, large asteroid impacts. The question is which impact or impacts are responsible? The Chicxulub Impact is probably the principal extinction event, but possibly another late Maestrichtian event may be responsible for the deposits observable in Badlands National Park. The Manson Impact is another possibility (Koeberl and others, 1996). This discussion proceeds by following our observations and interpretations of the stratigraphy up-section from the top of the Campanian, through the K-T boundary, and beyond. 


\section{The Pierre Shale}

Stoffer (1998) focused on resolving established ammonite biozonation of Gill and Cobban (1966) for the Western Interior region in Badlands National Park. Ammonites recovered within the confines of the park demonstrate that Searight's (1937) named members of the upper Pierre Shale in the Missouri River valley correlate to strata exposed in the park. These Pierre Shale members include from oldest to youngest: Verendrye Member (late Campanian), Virgin Creek, Mobridge, and Elk Butte Members (early Maestrichtian). The discovery of an ancient soil profile (paleosol) along an unconformable boundary between the Campanian and Maestrichtian strata provided impetus to search for additional evidence that sedimentation in the Western Interior Seaway was synchronous with established global sea-level fluctuations (Haq and others, 1987). The paleosol (up to $1 \mathrm{~m}$ ) is intermittently preserved beneath marine strata bearing reworked concretions containing fossils from older zones. Three locations where this can be observed include: 1) along Cedar Creek in Redshirt, South Dakota area (SE, Sec. 11, T5S, R10E); and 2) north of Wasta, South Dakota (SE, Sec. 9, T3N, R14E); and 3) along the South Fork of Sage Creek (NE, Sec. 24, T2S ; R14E [fig. 4]). The paleosol is probably preserved along "topographic highs" in the late Campanian Western Interior Seaway. The paleosol is synchronous with a major regression associated with a drop in sea-level at the close of Campanian time, about 71 million years ago. This lowstand is illustrated with a red "A" on a Campanian to late Paleocene sea-level curve modified after Haq and others (1987) compared with Badlands data after Stoffer (1998) (fig. 5). These structurally controlled topographic highs influenced the thickness and lithologic character of the nine uppermost ammonite zones of the Late Cretaceous (Gill and Cobban, 1958; Stoffer, 1998).

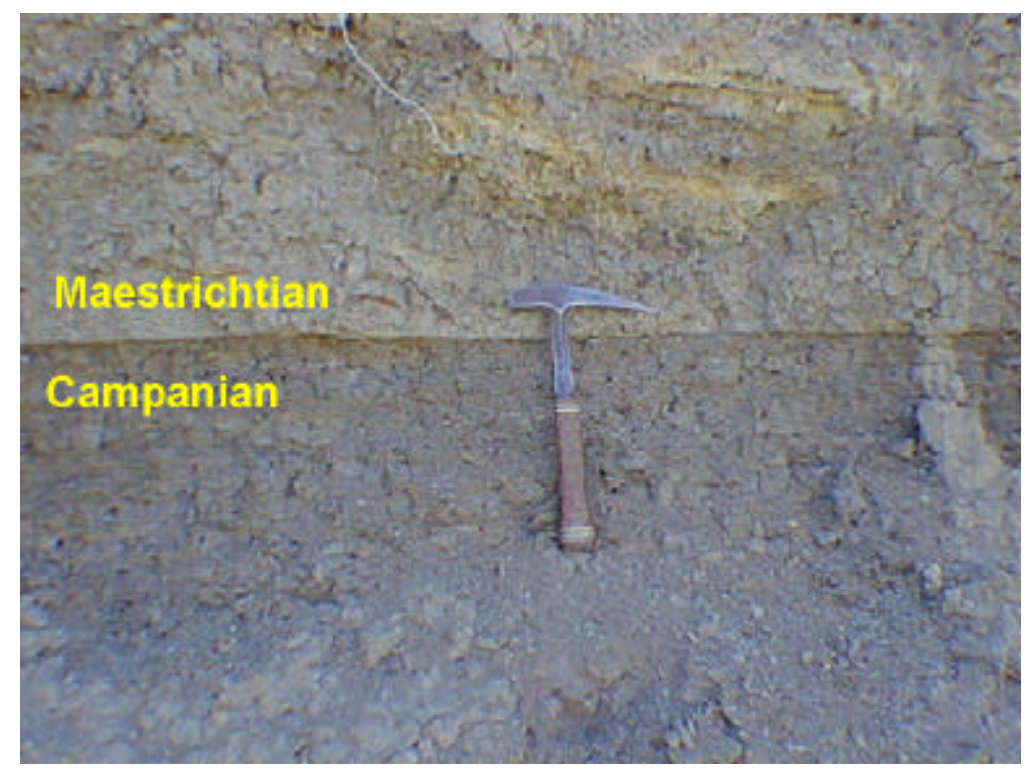

Figure 4. The Campanian-Maestrichtian boundary unconformity exposed along South Fork of Sage Creek (NE, Sec. 24, T2S, R14E; for location see fig. 1). 


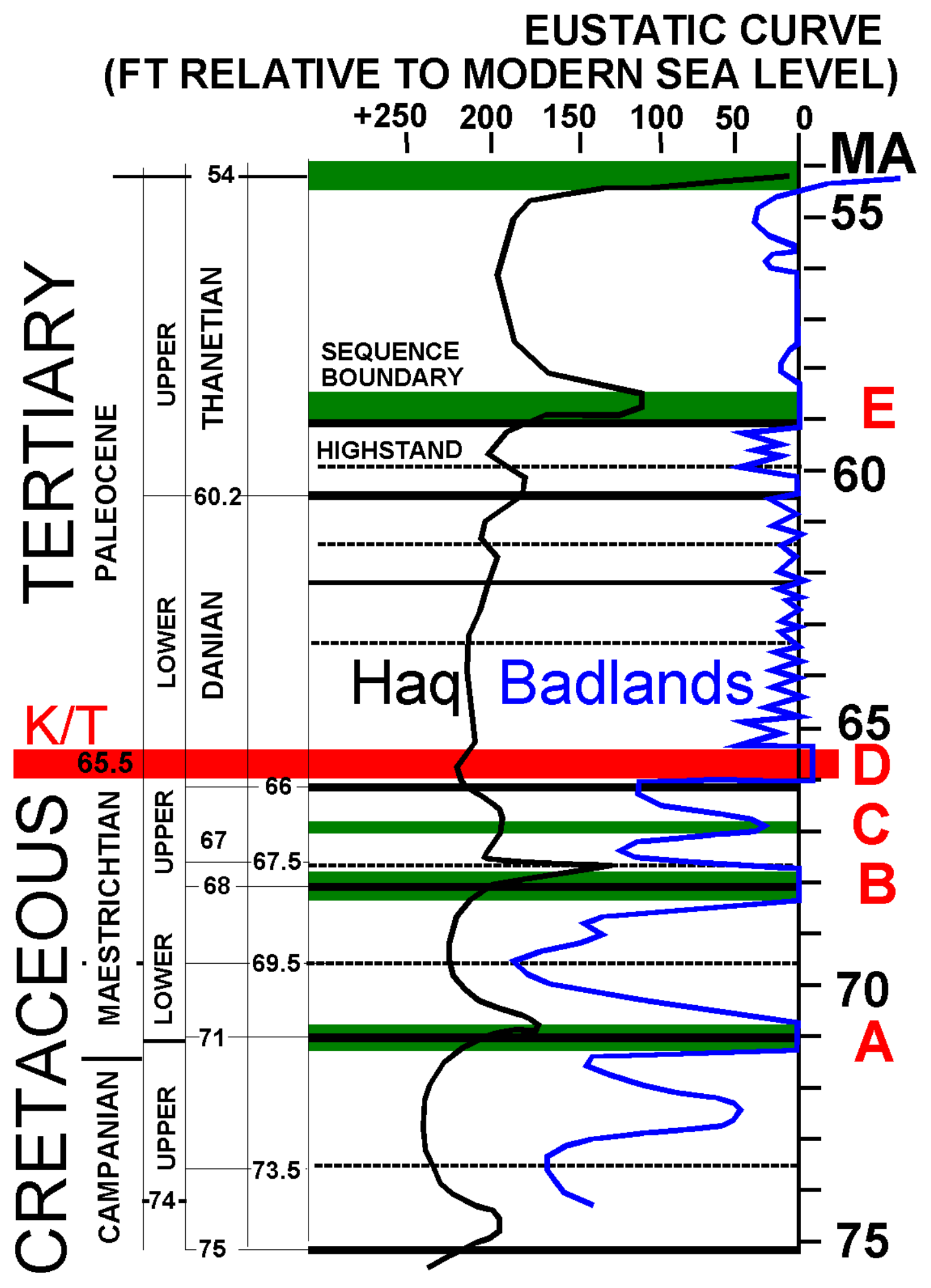

Figure 5. Comparison of the Haq and others (1987) sea-level curve with Badlands National Park data. 


\section{The Pierre Shale/Fox Hills Contact}

The late early Maestrichtian ammonite Baculites clinolobatus is a common fossil in the upper Pierre Shale (Mobridge Member) in and around Badlands National Park. Limestone concretion beds containing Baculites clinolobatus occur along the Pierre Shale/Fox Hills transition interval in eastern Wyoming (Gill and Cobban, 1966; Stoffer, 1998). Concretion beds bearing this fossil also occur in the transitional base of the Fairmont Member of the Fox Hills in western South Dakota (Pettyjohn, 1967) and in the Mobridge and lower Elk Butte Members of the Pierre near Mobridge, South Dakota (Searight, 1937). Based on the presence of Baculites clinolobatus and a high calcareous content of the shale, the Mobridge Member can be recognized in Badlands National Park, especially along the South Fork of Sage Creek where it is best exposed. Limestone concretions exposed in hilltops about two miles south of the Sage Creek Campground that have yielded Baculites clinolobatus have also yielded several specimens resembling Hoploscaphites birkelundi (Landman and Waage, 1993), a fossil from the lower Fox Hills in Wyoming. These observations show that the named lithologies (such as Fox Hills) are time transgressive.

Correlation of the Elk Butte Member through the Badlands' North Unit is the best measure of the complexity of the underlying structure. The Elk Butte section is best exposed in the drainage basin of Middle Fork in the central Sage Creek Wilderness Area (fig. 6). The Elk Butte Member consists of a dark-gray to loamy-black shale with several prominent bentonite beds (usually tightly carbonate-cemented), and an abundance of gray limestone concretions that rarely preserve a diagnostic ammonite of the Elk Butte Member-Jeletzkeytes spedeni (fig. 7).

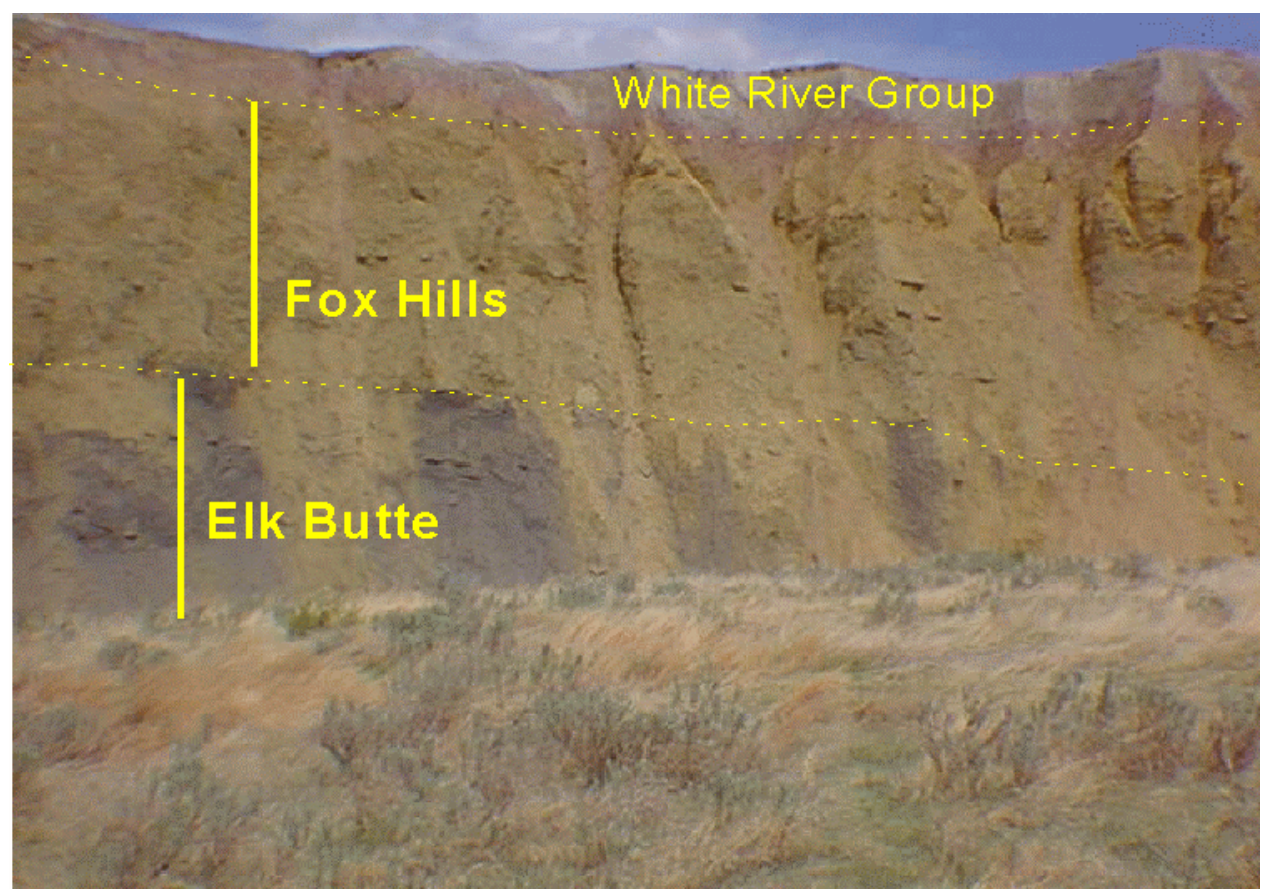

Figure 6. Cutbank outcrop along Middle Fork of Sage Creek (NE, Sec. 29, T2S, R15E - for location see fig. 1). 

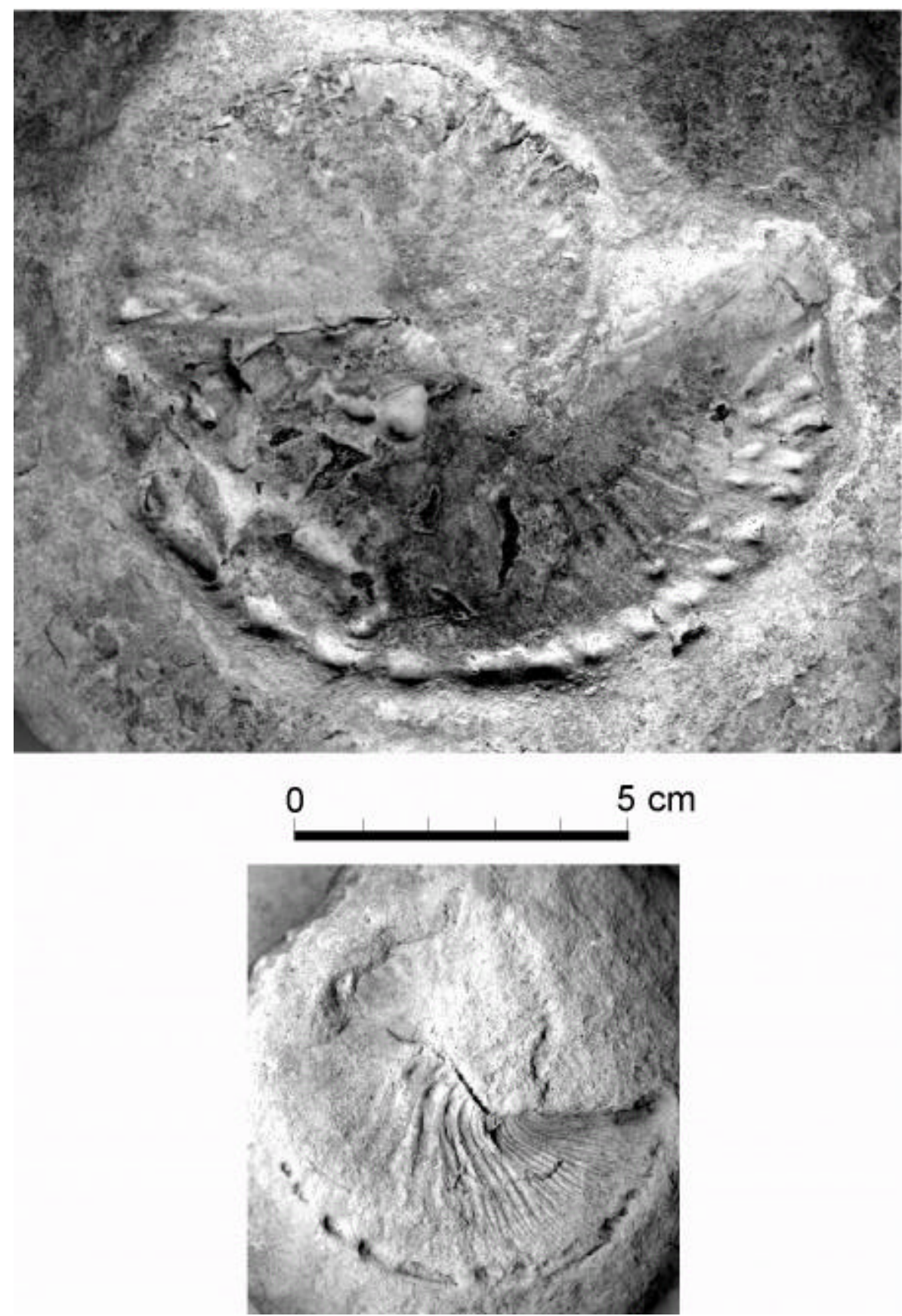

Figure 7. Jeletzkeytes spedeni from the Elk Butte Member of the Pierre Shale.

More than 30 meters of the Elk Butte Member crops out in the vicinity of the confluence of East Fork and Middle Fork of Sage Creek, whereas the Elk Butte is essentially missing from the crest of the Sage Creek Anticline near the Wilderness Access Trail Head locality (discussed below) and along the crest of another anticline in the headwater area of the South Fork of Sage Creek. A thin section of the Elk Butte Member is also exposed at the base of the Interior Zone along southern Dry Creek in the southwest corner of the wilderness area (SE, Sec. 24, T2S, R14E). In these locations, the base of the Fox Hills rests unconformably on top of an eroded surface of the Elk Butte Member. Intermittently throughout the wilderness area this 
unconformity is expressed as a bench-forming horizon of gray, tightly cemented calcareous shale which contains an abundance of large, yellow-weathering limestone concretions. In places, these concretions are so closely spaced that in some areas they are laterally linked into a dense concretionary horizon (up to 1 meter thick). Above this unconformity, the Fox Hills Fm. contains intermittent lag deposits of reworked pinkish to red nodules and concretions containing or consisting of baculitid and scaphitid ammonite fragments and vertebrate fossils (including rare shark teeth and mosasaur bones). Throughout the park, many large limestone concretions in the upper Mobridge and Elk Butte Members show heavy pedogenic alteration, possibly from multiple periods of subaerial exposure prior to a return of marine conditions in the late Maestrichtian (discussed below). On the crest of an anticline along South Fork, the Fox Hills Fm. rests unconformably on the Mobridge Member (the Elk Butte Member is entirely missing). Beds of deeply weathered and reworked Elk Butte sediments crop out in the hills around the Sage Creek Campground. The Elk Butte beds are also missing beneath younger strata along the crest of the Sage Creek Anticline northeast of the Sage Creek Bridge fault. Beds of deeply weathered limestone concretions are also exposed along the top of the Pierre Shale throughout the intermittent exposures of upper Elk Butte Member exposed along the East Fork of Sage Creek, and along the deepest ravines in the Conata Creek/Dillon Pass area. Along Conata Creek near the Badlands Loop Road, up to 10 meters of the upper Elk Butte Member crops out intermittently and consists of a very dark, fissile shale. Near the confluence of East Fork and Middle Fork of Sage Creek, the Elk Butte is more than 30 meters thick. This discussion demonstrates that structure affects the distribution and character of the Fox Hills and its underlying unconformity (see fig. 3). Elsewhere in the region, the Fox Hills Fm. and the underlying unconformable boundary are missing as a result of erosion prior to deposition of younger strata.

\section{The Badlands' “Thin or Missing”' Fox Hills Problem}

Along the western flank of the Black Hills and in the type Grand River Valley region of northern South Dakota, the Fox Hills Formation is quite thick, as much as 100 meters or more (Landman and Waage, 1993). Pettyjohn (1967) described more than 100 meters of Fox Hills in northwestern South Dakota near Union Center and Fairmont. However, in Badlands National Park, such as along the South Fork of Sage Creek, the distance between the top of the Pierre Shale and the base of the White River Group is only a few meters. This observation supports the claim that the "Fox Hills" (or late Maestrichtian strata) is either thin or missing as a result of erosion. However, paleontologic, geochronologic, and sedimentologic data presented below demonstrate that all named members of the Type Fox Hills (Grand River, South Dakota region) correlate to thin Fox Hills units preserved intermittently throughout the Badlands National Park area.

The basal White River Group is the most obvious unconformity in the region. A thin, basal Eocene-age unit, the Chamberlain Pass Formation (Evans and Terry, 1994; Terry and Evans, 1994), is composed of white channel sandstone and red overbank mudstones up to $15 \mathrm{~m}$ thick. This unit rests unconformably on the top of the orange and red pedogenically altered sediments of the top of the Interior Zone. The character of this unconformity, however, is poorly resolved in relation to regional structures in underlying Cretaceous and Paleocene strata. In contrast, the thinning and pinching-out of units in the Eocene and Oligocene section across the crest of the Sage Creek Anticline is very apparent in the Dillon Pass area and in headlands in the Pinnacles along the East Fork of Sage Creek. The thinning of the Scenic Member of the Brule 
Formation is particularly evident in the well-exposed badlands when viewed northwestward from the Dillon Pass Overlook along the Badlands Loop Road. In many places the basal White River gravels of the Chamberlain Pass Formation occur in channels carved into the older underlying strata. In the North Unit, the basal Chamberlain Pass Formation gravels occur throughout the structural low area generally along the southern East Fork drainage area and throughout the central South Fork and Dry Creek drainage basin (fig. 8). This suggests that uplift of the anticlines maintained moderate topographic highs in early Tertiary time that survived stream erosion prior to the later engulfing influx of White River sediments.

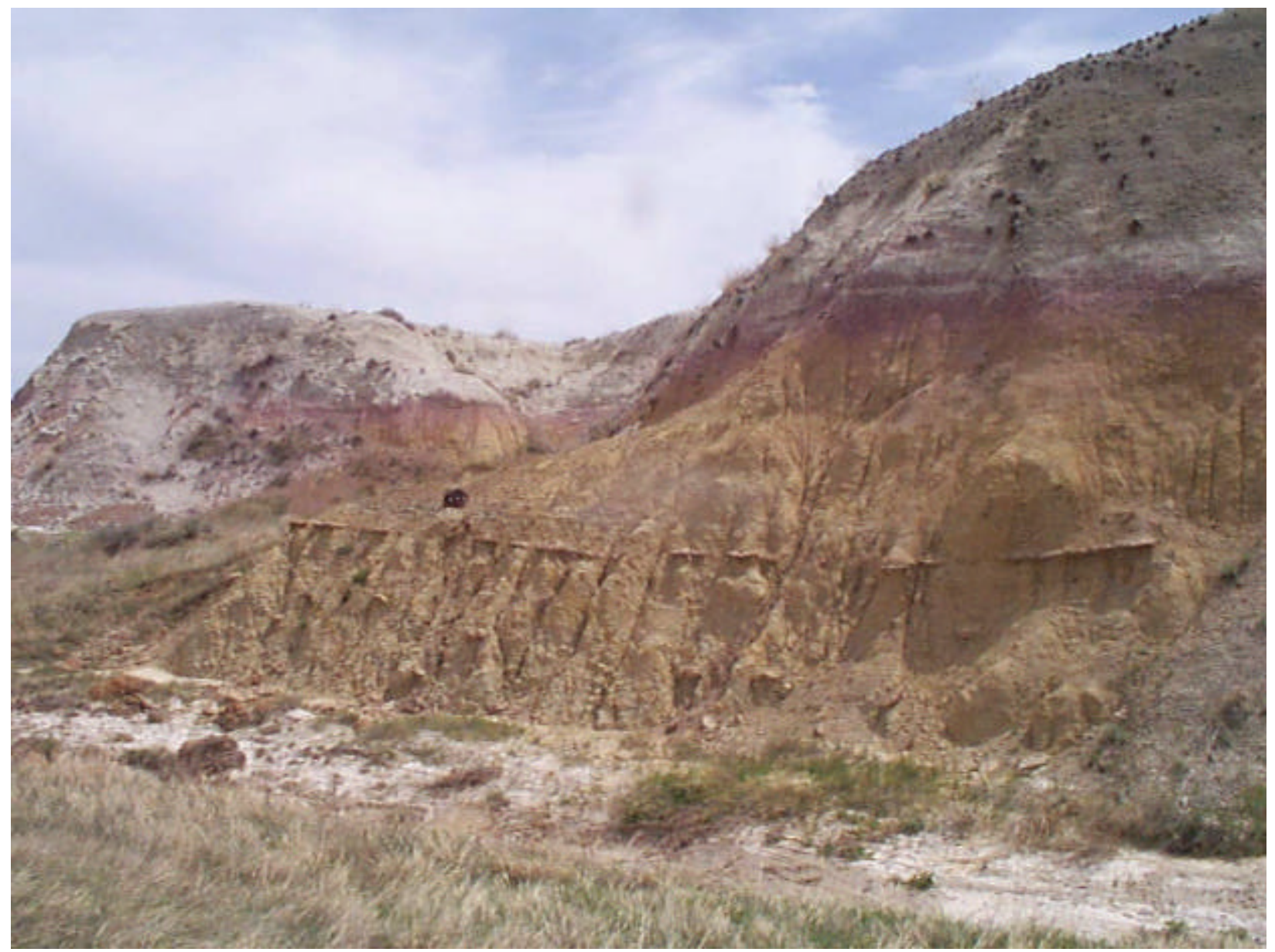

Figure 8. Outcrop along Dry Creek in NE, Sec. 25, T2S, R14E. The prominent sand sheet about 3 meters above creek level marks the top of the Disturbed Zone in the Fox Hills Fm. The red clay (paleosol) and channel gravels (white) define the base of the White River Group (for location see fig. 1).

\section{A Fox Hills Intraformational Unconformity}

Limestone concretion beds within the Mobridge and Elk Butte Members of the Pierre Shale are well developed along the South Fork of Sage Creek, particularly a conspicuous bed of large gray concretions in the upper Mobridge Member that have yielded scarce specimens of the ammonite Jeletzkeytes verrucosus, $n$. sp. (Neil Landman, oral commun, 1997). However, along a drainage east of White Butte, the same concretion bed appears to have been partially scoured away by erosion, defining an unconformity (fig. 9). To the east along the East Fork of Sage 
Creek in central Sec. 19, T2S, R15E, this unconformable surface preserves a red weathered zone (a paleosol formed during subaerial exposure) between marine-deposited gray shale above and below.

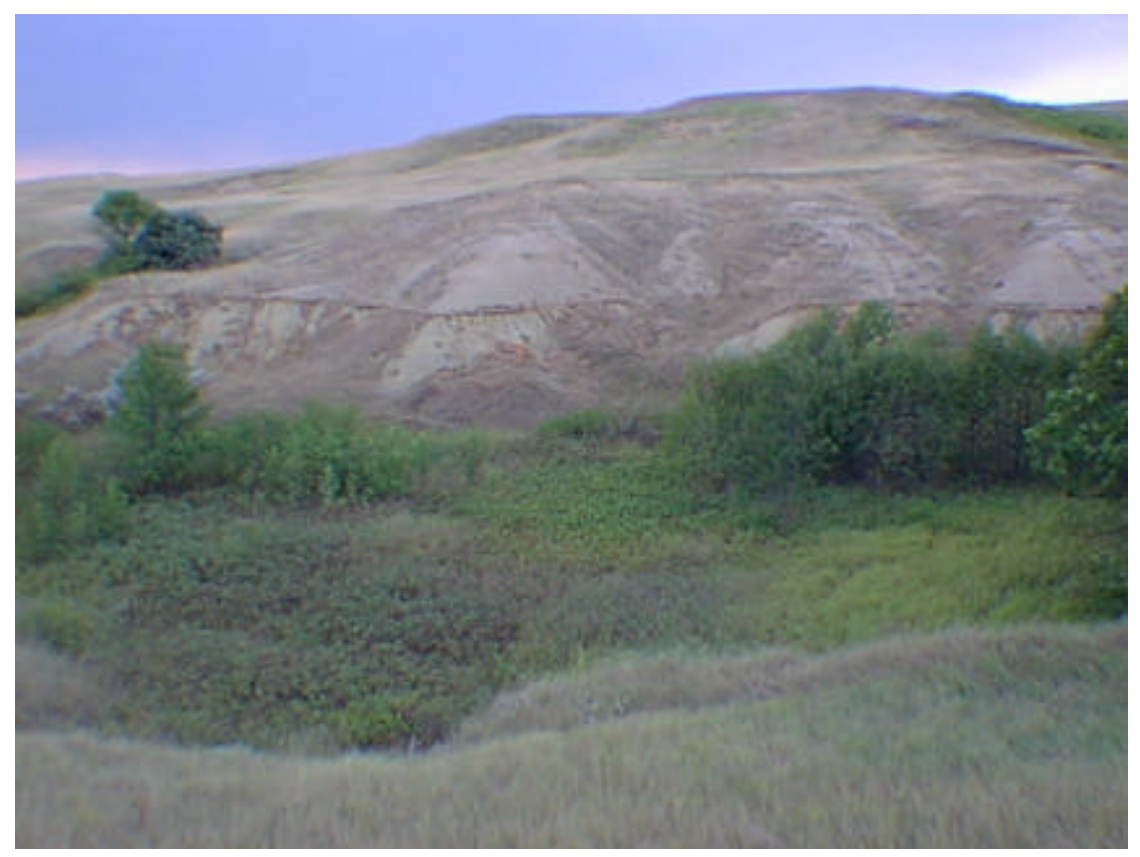

Figure 9. A dark-brown, limonite-enriched concretion layer highlights an unconformity between the Elk Butte Member of the Pierre Shale from the overlying marine mudrocks of the Fox Hills Fm. (near White Butte in SE, Sec. 6. T2S, R15E, for location see Fig. 1).

The shale overlying the unconformity has yielded poorly-preserved ammonite fragments, belemnites, tiny ribbed clams, arthropod fragments and mosasaur bone, and displays an abundance of bioturbation features consistent with the typical marine rocks of the Western Interior Seaway. Perhaps what is most significant is what has not been found. No specimens of the Fox Hills scaphitid ammonite, Hoploscaphites nicolletii, have been recovered within the park, although a single specimen was recovered from upper Elk Butte facies outcrop 20 kilometers north of the park west of Creighton, South Dakota (see Fig. 1). This ammonite occurs in abundance in the lower to middle type Fox Hills in the Grand River region of South Dakota.

The tiny ribbed clams have been identified as Nucula sp. (fig. 10.). These fossils suggest that strata in the upper part of this unit correlate with the upper Timber Lake Member of the middle to upper Fox Hills (Speden, 1970). In the park, this upper "Fox Hills" unit ranges between 6 to 8 meters thick near White Butte. These fossils have been observed in equivalent strata throughout Badlands' North Unit and in outcrops west of Creighton, South Dakota. Along the South Fork of Sage Creek this upper Fox Hills unit is very thin and deeply weathered, or is covered by younger sediments. Data presented below demonstrate that this upper shale unit is equivalent to the Jeletzkeytes nebrascensis Zone of the Fox Hills Fm. and is of latest Maestrichtian age. 


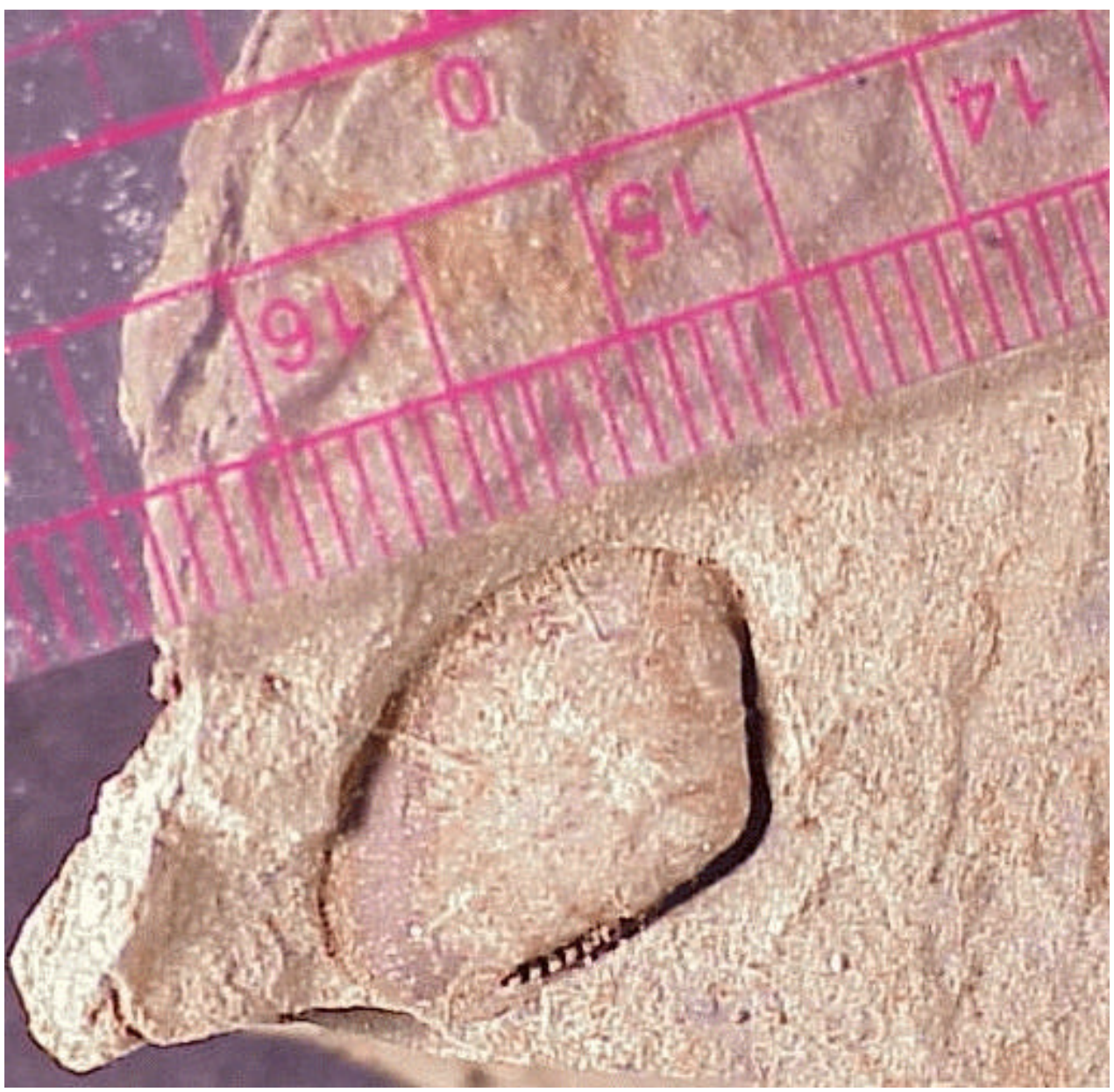

Figure 10. Nucula sp. - a tiny clam that occurs just below the Disturbed Zone. This clam is reported from the upper Timber Lake Member of the type Fox Hills Fm. (Speden, 1970). This specimen is from the Creighton locality (see fig. 1).

\section{The Jeletzkeytes nebrascensis Zone of the Fox Hills in Badlands National Park}

Pettyjohn (1967) supported Ward's $(1922,1924)$ interpretations that the "Interior Phase" (or "Interior Formation") of the Badlands region is equivalent to the Fox Hills Fm. He added, however, that "the multicolored weathered zone becomes older in the section and is well developed on the Pierre near Sage Creek in Badlands National Monument." New data presented here suggest that this later interpretation is not completely accurate. Strata of latest Cretaceous age (late Maestrichtian) and younger are locally preserved within and beneath the Interior Zone weathering profile throughout the Sage Creek Wilderness Area, except where it is missing along the erosional surface (unconformity) carved by the pre-White River Group stream drainage system.

Correlation of the uppermost Fox Hills strata across northern South Dakota into the Badlands region was first established by Pettyjohn (1967). He described strata bearing Discoscaphites sp. in an exposure of the "Bullhead Member" of the Fox Hills Fm. 5 miles south of Creighton, South Dakota. Pettyjohn stated that this unit is overlain by a sequence of buff sand and sandstone, light-green shaley sand and silt, and thin layers of purple clay-shale in which the 
upper part contains many Ophiomorphia sp. and a few Belemnitella sp. and Ostrea sp. He named this upper unit the "Enning facies" (after similar exposures in the upper part of his White Owl Creek Member of the Fox Hills near Enning, SD). In Pettyjohn's Fairpoint, South Dakota type Fox Hills locality, the Enning facies overlies more than 200 feet of crossbedded sandstone of his Fairpoint and lower White Owl Creek Members. The dividing line between these two members is a terrestrial unit that Pettyjohn named the Stonyville coal facies. He added that the upper White Owl Creek Member is equivalent in age with the Hell Creek in the type area of the marine Fox Hills. Therefore, since the Enning facies, bearing marine fossils (belemnites), overlies terrestrial coal facies, it represents a last marine transgression into the Western Interior region before the close of the Cretaceous. Using the global geochronology curve of Haq and others (1987), this would most likely be synchronous with a major drop in sea-level and resulting marine regression that peaked about 67.7 million years ago (see the red "B" on fig. 5).

The Enning facies is therefore time equivalent to the Breien Member, a thin marine facies within the dominantly terrestrial Hell Creek Fm. in central southern North Dakota (Frye, 1964). Kennedy and others (1998) include this unit in the upper Jeletzkeytes nebracensis Zone in the uppermost exposures along portions of the Missouri River Valley of South Dakota. Jeletzkeytes nebracensis (Owen, 1852; called Discoscaphites by Pettyjohn, 1967) represents the youngest Cretaceous (late Maestrichtian) macrofossil zone recognized in the Western Interior.

${ }^{87} \mathrm{Sr} /{ }^{86} \mathrm{Sr}$ data derived from belemnites in Badlands National Park corroborate that the Jeletzkeytes nebrascensis Zone occurs in Badlands National Park (fig. 10). Belemnites were found in a marl bearing a variety of marine invertebrate traces and fossils. This interval rests conformably on top of the Elk Butte Member and is capped by the chaotic bedding of the Disturbed Zone (discussed below). Belemnites were found in outcrops (scattered throughout ravines in Sec. 3, T2S, R15E) in the vicinity of the Wilderness Access Trailhead. All belemnites recovered are broken, and some are worn, suggesting some degree of reworking. Scaphitid ammonite fragments and immature specimens have been recovered from the interval, but none of the specimens recovered were clearly identifiable as the Jeletzkeytes nebrascensis Zone species. In many ways, the discovery of the belemnites was a turning point in our investigations. Many published investigations into the geochemical character of Mesozoic marine waters have utilized data derived from the calcareous skeletons of belemnites. Reports that describe ${ }^{87} \mathrm{Sr} /{ }^{86} \mathrm{Sr}$ methodology and contain data derived from belemnites and mollusk shells include studies by Sugarman and others (1991) for the Late Cretaceous of the Atlantic Coastal Plain, and in the Western Interior region by McArthur and others (1993) and Stoffer (1998). We chose to test ten belemnites from Badlands, and included ten belemnites from the Navesink Fm. in New Jersey for comparison and validation of our data with the previously published information (fig. 11). Using the strontium isotope laboratory managed by Paul Fullager (University of North Carolina, Chapel Hill) and the stable isotope services of Kreuger Enterprises, Inc., we had the twenty specimens analyzed for standard ${ }^{87} \mathrm{Sr} /{ }^{86} \mathrm{Sr},{ }^{13} \mathrm{C} /{ }^{12} \mathrm{C}$, and ${ }^{18} \mathrm{O} /{ }^{16} \mathrm{O}$ values. Table I shows our data.

Figure 12 shows the plot of the New Jersey and South Dakota belemnites in relation to previously published ${ }^{87} \mathrm{Sr} /{ }^{86} \mathrm{Sr}$ and other geochronology data compiled for the Western Interior (McArthur and others, 1994, Obradovich and others, 1993; and Baardsgaard and others, 1993) and for the Atlantic Coastal Plain (Sugarman and others, 1991). The data for the New Jersey belemnites fall exactly in line with previously tested samples from the Navesink Formation reported by Sugarman and others (1991). By comparison with previously published values, the Sr values of the Badlands belemnites indicated that they were younger than any other Cretaceous 
Western Interior fossils previously tested in this manner (McArthur and others, 1994). A recently tested value for a belemnite from the Jeletzkeytes nebracensis Zone from the type Fox Hills yielded a value of 0.707801 (Neil Landman, oral commun., 1998). Using the data from Figure 12 , the Badlands' belemnites are consistent with a age of $67.6 \pm .5 \mathrm{Ma}$. The youngest value of .707822 is about $67.1 \mathrm{Ma}$ which closely matches range values for ${ }^{87} \mathrm{Sr} /{ }^{86} \mathrm{Sr}$ that were reported from the interval from 40.0 meters to 0.05 meter below the K-T boundary in the massive Maestrichtian section near Bidart, France (Nelson and others, 1991). These values also closely matched K-T values for the New Jersey Coastal Plain described by Sugarman and others (1991). Considering the belemnite data, we determined that the K-T boundary should be lower in the Badlands National Park than previously recognized.

Table 1. Stable isotope data derived from New Jersey and South Dakota belemnites.

\begin{tabular}{|l|l|l|l|}
\hline SAMPLE & ${ }^{87} \mathrm{Sr} /{ }^{86} \mathrm{Sr}$ & ${ }^{13} \mathrm{C} /{ }^{12} \mathrm{C}(\mathrm{smow})$ & ${ }^{18} \mathrm{O} /{ }^{16} \mathrm{O}(\mathrm{smow})$ \\
\hline SD A11 & .707818 & 29.1 & 0.0 \\
\hline SD C32 & .707815 & 28.9 & 0.9 \\
\hline SD E03 & .707811 & 29.5 & 1.9 \\
\hline SD G34 & .707812 & 29.2 & 0.1 \\
\hline SD I25 & .707818 & 28.8 & 1.0 \\
\hline SD K16 & .707806 & 30.2 & 0.5 \\
\hline SD M27 & .707801 & 29.8 & 1.1 \\
\hline SD 018 & .707812 & 29.4 & 0.7 \\
\hline SD Q09 & .707803 & 29.2 & 1.0 \\
\hline SD S10 & .707822 & 28.8 & 1.1 \\
\hline mean (st. dev.) & $.707812(.000006)$ & $29.3(0.4)$ & $0.8(0.5)$ \\
\hline NJ B01 & .707788 & 31.5 & 1.3 \\
\hline NJ D22 & .707782 & 31.4 & 1.0 \\
\hline NJ F23 & .707773 & 31.5 & 1.2 \\
\hline NJ H24 & .707766 & 31.5 & 0.5 \\
\hline NJ J15 & .707759 & 31.2 & 0.4 \\
\hline NJ L26 & .707764 & 31.4 & 1.0 \\
\hline NJ N07 & .707787 & 31.5 & 1.1 \\
\hline NJ P38 & .707793 & 31.4 & 1.4 \\
\hline NJ R19 & .707775 & 31.3 & 0.7 \\
\hline NJ T20 & .707776 & 31.7 & 1.0 \\
\hline mean (st. dev.) & $.707776(.000010)$ & & \\
\hline
\end{tabular}




\section{Belemnitella sp. Western Interior Seaway Badlands National Park, South Dakota Sec. 3, T2S, R15E}
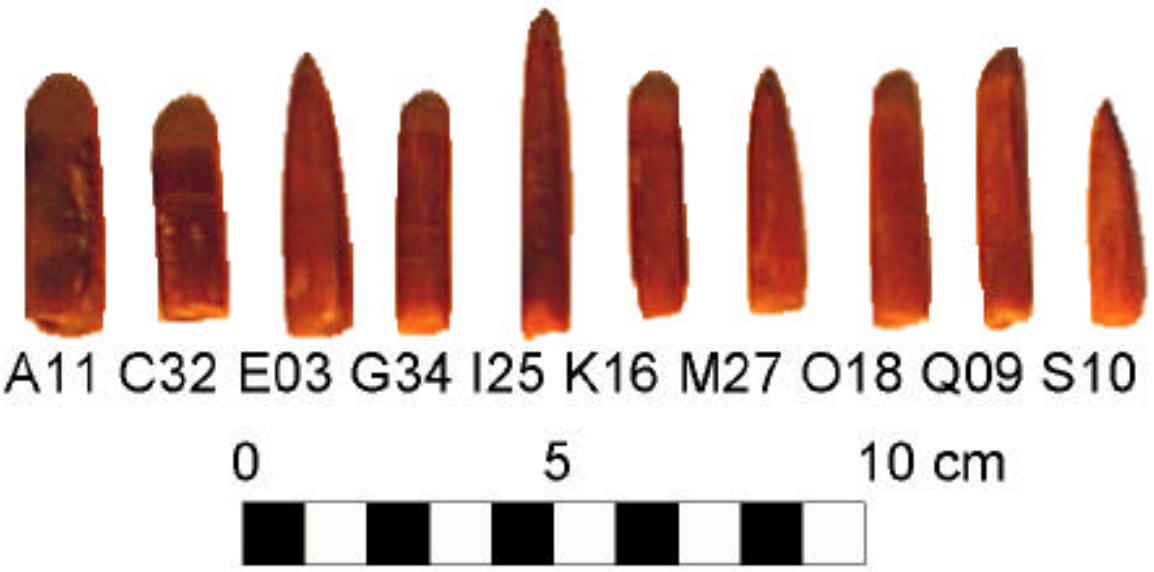

Belemnitella americana Atlantic Coastal Plain Monmouth County, New Jersey Big Brook Locality
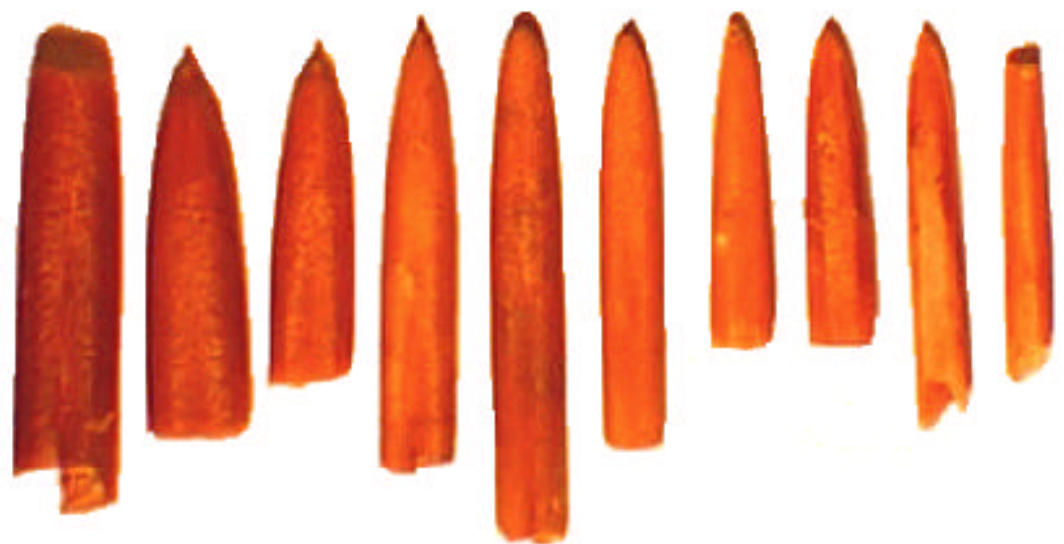

B01 D22 F23 H24 J15 L26 N07 P38 R19 T20

Figure 11. Belemnites used for strontium isotope geochronology. 


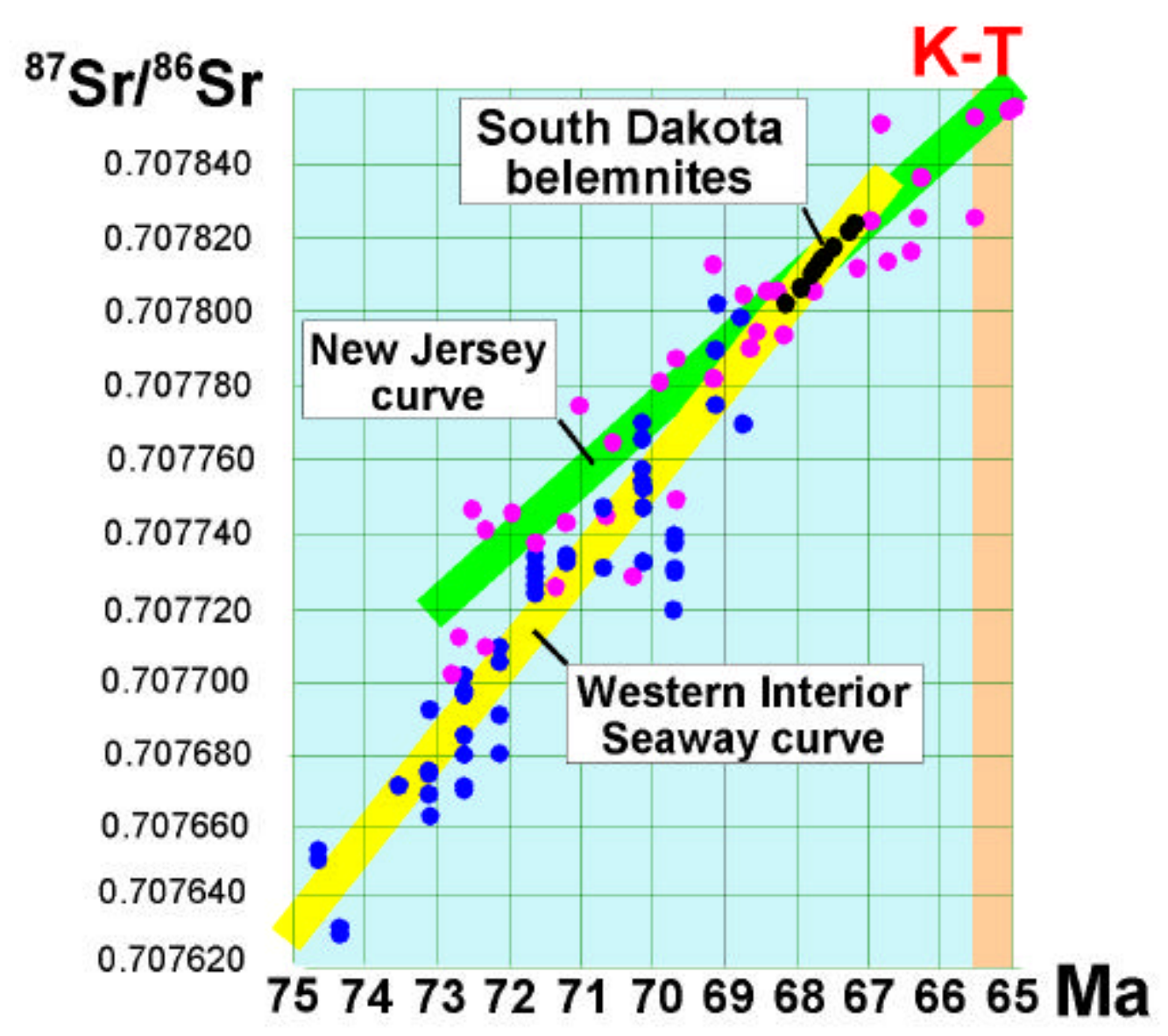

Figure 12. Strontium isotope data: purple dots represents New Jersey data (Sugarman and others, 1991); blue dots represent Western Interior data (McArthur and others, 1994; Stoffer, 1998); red dots represent belemnite data from Badlands National Park.

The belemnite data support the interpretation that both eustatic changes in sea-level and tectonism controlled sedimentary facies relationships in the Fox Hills Fm. Figure 13 shows the Fox Hills sequence in the Badlands where the land was "rising" compared with Pettyjohn's (1967) section in the southern Williston Basin where the land was concurrently "sinking." In this scenario, in areas where the land is rising (as in the Badlands) only the high-stand systems tracts are preserved, and the low-stands are preserved as unconformities. 


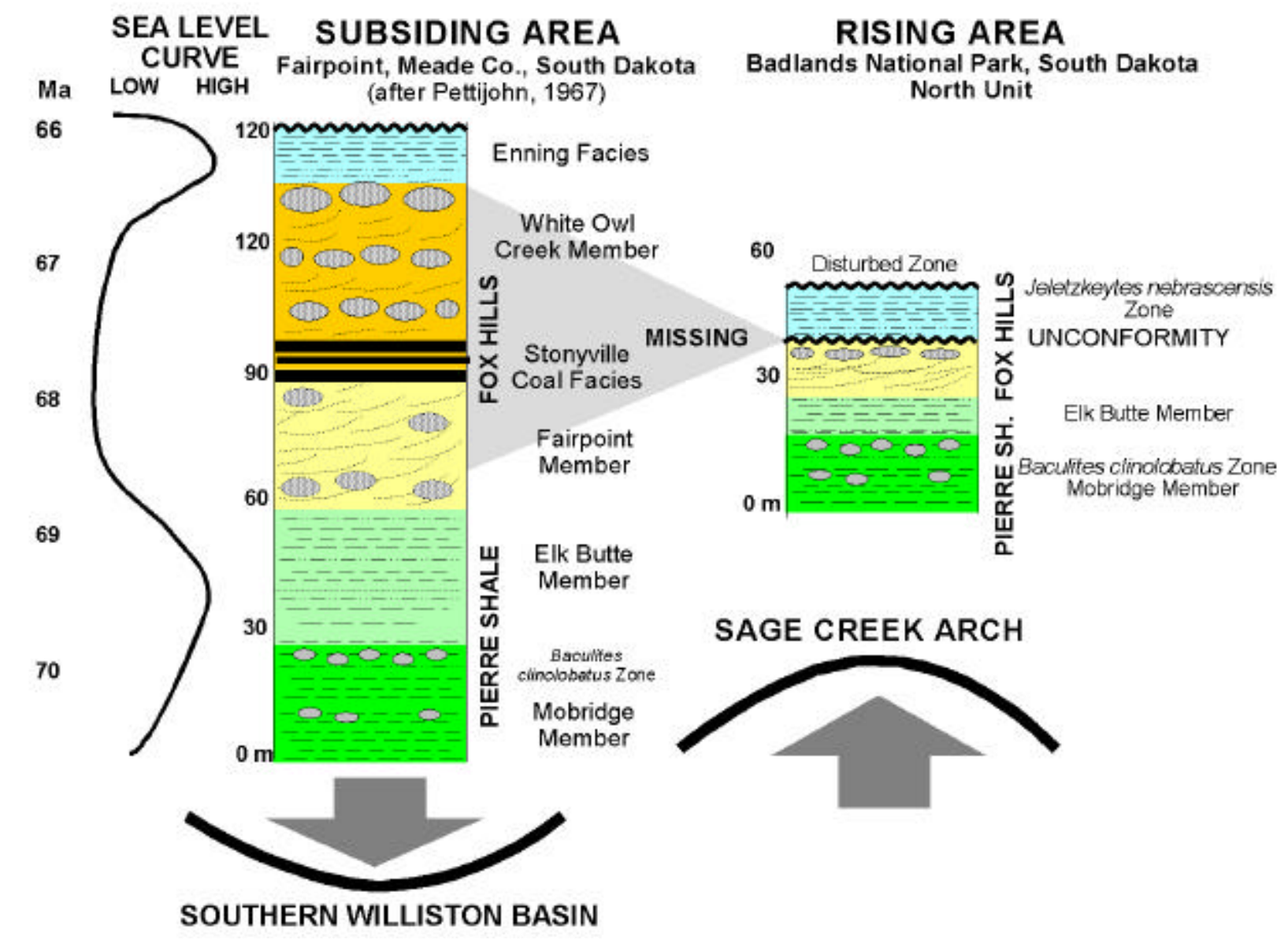

Figure 13. Illustration of how changing sea-level and tectonism influenced the formation and distribution of facies of the Fox Hills Fm.

\section{The Latest Maestrichtian Age Dilemma in South Dakota}

The discussion above does not entirely reflect the uncertainty of late Maestrichtian regional and global stratigraphic correlation and geochronology issues, particularly in relation to current knowledge of inferred massive extraterrestrial impacts from the early Maestrichtian to the K-T boundary. The South Dakota story for the late Maestrichtian and K-T boundary is muddled by many confounding problems: the vast area, accessibility issues, and a general lack of detail relating to regional stratigraphic correlation. As Gill and Cobban (1973) demonstrate, during the late Maestrichtian the region was affected by an overall regression of the Western Interior Seaway shoreline eastward from Wyoming and Montana into South Dakota. Active Larimide tectonism in the Maestrichtian also affected the regional sedimentary framework. This includes the uplift of the Sage Creek Arch and the Black Hills, and the subsidence of the Williston Basin and other basins in the region. Many Late Cretaceous stratigraphy-related issues remain unresolved in the Western Interior region, particularly the correlation of terrestrial facies (Hell Creek Fm) to time-equivalent transitional facies (Fox Hills Fm.) and fully marine facies (Pierre Shale). 
The range values for ${ }^{87} \mathrm{Sr} /{ }^{86} \mathrm{Sr}$ that were reported from the 40.0 to 0.05 meters interval below the K-T boundary in the massive Maestrichtian section near Bidart, France, (Nelson and others, 1991) are reason for suspicion in using this methodology for resolving K-T boundary issues. McArthur and others (1994) describe rapid shifts and plateaus in the strontium-isotope curve in the latest Maestrichtian; these anomalies in the late Maestrichtian curve are also reported elsewhere in the literature. Hagstrum (2000) suggests that a probable late Maestrichtian wet impact in the Pacific Ocean west of Mexico (the Socorro Impact-18.8EN, 111EW) might be responsible or related to an ${ }^{87} \mathrm{Sr} /{ }^{86} \mathrm{Sr}$ "peak" that occurred roughly between 68 and $67 \mathrm{Ma}$ (the age values inferred by the belemnite data discussed above). His data suggest that the Disturbed Zone data in the Badlands region might be more consistent with this event rather than the Chicxulub K-T impact. Jonathan Hagstrum (USGS; oral commun., 2000) suggests that oceanic impacts may cause much greater seismic energy transfer into the Earth and less atmospheric effects than a terrestrial impact.

The exact age of the Disturbed Zone will remain elusive until additional paleontological or other data clearly resolve the age of the uppermost Interior Zone section in the Badlands section. The discussion below outlines observations and interpretations that suggest the possibility that the more than one impact may have occurred, and that some evidence suggests that the Disturbed Zone represents a probable association with the Chicxulub K-T impact.

Correlation of the Disturbed Zone to the Type Fox Hills in north central South Dakota (Corson County) described by Waage (1968) might support an interpretation for an earlier late Maestrichtian event. Waage described a widespread zone of "contorted bedding" between the lower "Bullhead Lithofacies" and "Colgate Lithofacies" within the Fox Hills Formation (illustrated on plates 9 and 10 within the 1968 text). Waage (1968) reports the occurrence of at least one carnivorous dinosaur claw and a fragment of the scaphitid ammonite "Discoscaphites" (now named Jeletzkeytes nebrascensis by Landman and Waage, 1993) from an undetermined distance above the contorted bedding layer. This contorted-bedding interval occurs as much as 52 feet below-lignite bearing strata that Waage calls Hell Creek Fm. The association of Jeletzkeytes nebrascensis with this contorted bedding is significant in that it suggests that Waage's "contorted bedding" is likely time synchronous with the Disturbed Zone in Badlands National Park. This question remains. Is Waage's overlying Hell Creek really Maestrichtian-age Hell Creek Fm., or is it Paleocene Fort Union-equivalent strata? Dinosaur-bearing Hell Creek Fm. is well-known from western South Dakota and especially Montana, where K-T impact eject materials are known to occur. Although dinosaur remains are well-known from the Hell Creek Fm. in the region west of Waage's contorted beds, we have not verified that dinosaurs definitively occur above this interval at Waage's locality. The Hell Creek bone beds of western South Dakota may be the terrestrial deposits that are age equivalent of the marine Fox Hills units in Corson County, South Dakota. In North Dakota, the Breien Member of the Hell Creek Fm. is definitively a marine unit that according to Kennedy and others (1998) incorporates the Jeletzkeytes nebrascensis Zone. The Corson County locality needs thorough reinvestigation to demonstrate that actual dinosaur remains, rather than stream reworked bone fragments occur above the contorted beds. The abundance of reworked fossils on modern beaches demonstrates that lone fossil fragments are not satisfactory for dating rock units. However, assuming dinosaurs went extinct at the K-T, should articulated dinosaur remains be found above the contorted beds, then the contorted beds would definitively be late Maestrichtian. The important thing to emphasize, however, is the occurrence of Waage's contorted beds in associated with the Jeletzkeytes nebrascensis Zone in the Corson County region, nearly 180 miles from the Badlands 
outcrop area; this strongly suggests that a widespread, intense seismic event affected the entire region sometime around 67 million years ago. The age of the Chicxulub Impact is around 65.6 Ma.

Another possibility is that future research might show that the Badlands' Disturbed Zone might correlate with the Manson Impact or another impact. Anderson and others (1996) reported that the Manson Impact has an age of $73.8 \mathrm{Ma}$ - roughly equivalent in age to the oldest Cretaceous rocks exposed in Badlands National Park (latest Campanian). However, no evidence of this impact has yet been recognized in the park-area outcrops. Nearly all published ages and characteristics of the Manson impact event were reported before discovery of the Disturbed Zone and other units possibly related to extraterrestrial impact deposits in Badlands National Park.

\section{K-T BOUNDARY LOCALITIES IN BADLANDS NATIONAL PARK}

Recent fieldwork and laboratory tests have added additional information to support our interpretations that Badlands National Park is host to important K-T boundary localities. Significant contributions from the field include the discovery of additional diagnostic fossils suitable for high-resolution correlation of stratigraphic units among several localities. Laboratory analyses include the thermal paleomagnetic determination of seven oriented samples from a section in the park. Additional petrographic studies and field observations also support our conclusions. We have expanded the extent of our original "slump zone" (Stoffer and others, 1997) to an even greater aerially distributed "Disturbed Zone" that extends throughout the North Unit and northward of Wall, South Dakota, by at least 17 miles. The discussion below focuses on the K-T boundary sections in three study area in Badlands National Park: Wilderness Access Trailhead area (WATH), Grassy Tables Overlook area (GTO), and the Dillon Pass/Conata Creek area (DPCC) (see fig. 1).

\section{WILDERNESS ACCESS TRAILHEAD AREA (WATH)}

Figure 14 shows the K-T boundary section in Sec. 3, T2S, R15E. This site is located about 0.2 mile south of the Wilderness Access trailhead parking area along the Sage Rim Road. The site is accessible by a heavily used bison trail leading southwest from the trailhead parking area. The outcrop is located south of a prominent fault offsetting the Fox Hills, Chamberlain Pass, and Chadron Formations and just below (west) of a linear series of small "yellow mounds." This site is where Pettyjohn (1966) used the name "Yellow Mounds" for the brightly yellowcolored stratigraphic interval overlying sand sheets he recognized as Fox Hills Sandstone.

At WATH, the presence of the Fox Hills intraformational unconformity is revealed by a break in slope above a grass-covered surface displaying an abundance of large brown-weathering concretions that define the eroded top of the Elk Butte Member. The thickness of the strata between the concretion bed and the base of the Disturbed Zone (shown in fig. 14) is about 5 meters. About 5 dozen belemnite fragments were recovered within a 300 meter radius of this locality, but nowhere else. One belemnite was found within a meter below the Disturbed Zone. No belemnites were found within or above a greenish, glauconitic, sandy marl unit indicated in the fig. 14. Below the glauconite, bedding is not obvious, probably because of heavy bioturbation and poor exposure. The occurrence of mosasaur bones, belemnites, and other shell hash suggests that the seaway hosted a diverse Cretaceous marine fauna before deposition of the glauconite layer. 


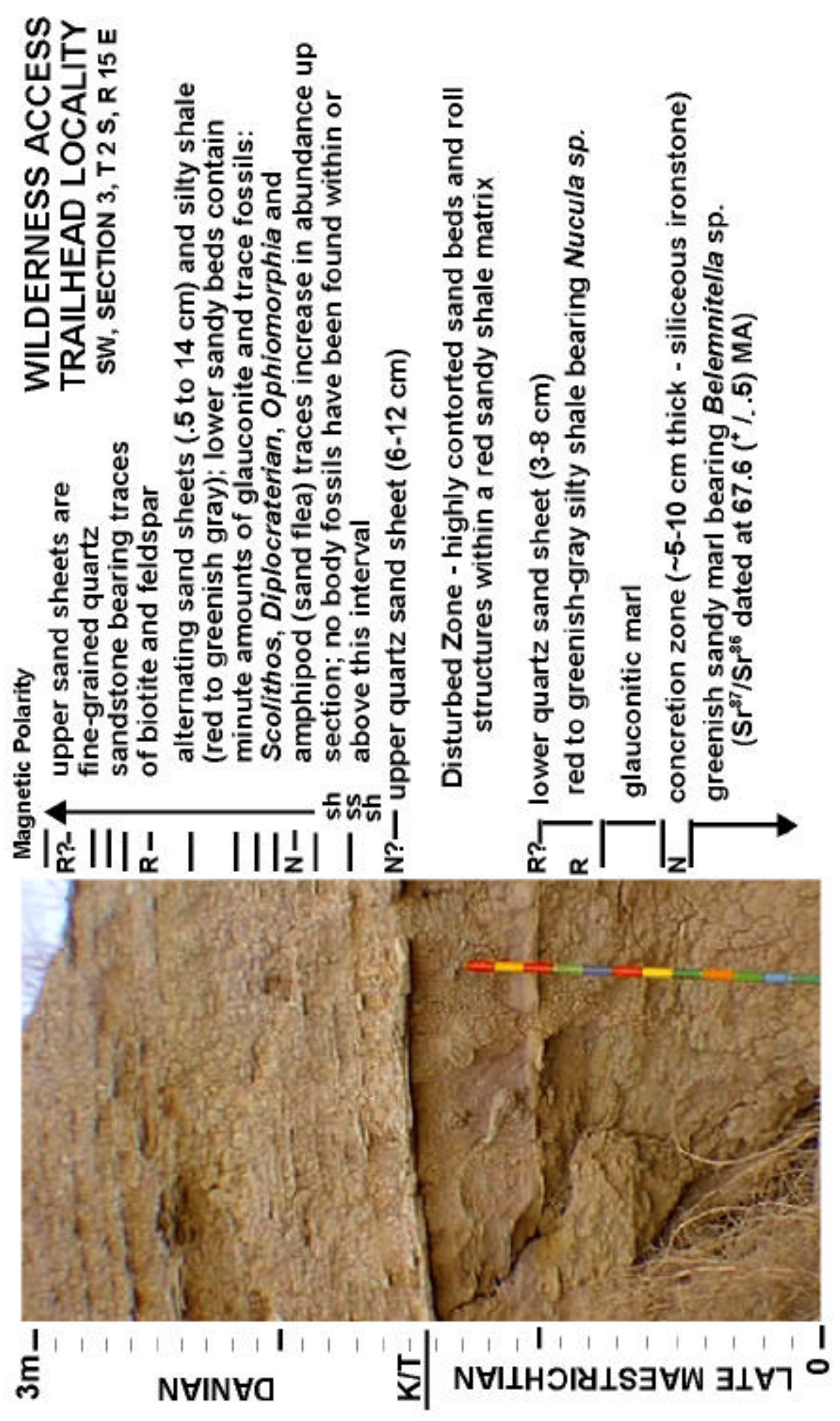

Figure 14. The Wilderness Access Trailhead (WATH) locality K-T boundary section. 
The glauconitic marl is a distinct layer that stands out in sharp contrast to the underlying beds, and particularly with the underlying Elk Butte Member, which is void of glauconite. At the WATH locality, the glauconite bed is poorly exposed, but it appears mostly bioturbated in hand samples. The glauconite layer is better exposed elsewhere. The glauconite marl layer contrasts with an overlying a $20 \mathrm{~cm}$-thick, well-laminated, red to greenish-gray silty shale that bears tiny clams (about $0.5 \mathrm{~cm}$ maximum dimension) that most closely resemble Nucula sp. described in the Timber Lake Member of the Fox Hills by Speden (1970) (see fig. 10). These small clams occur in a finely laminated red clay unit that suggests that environmental conditions within the Western Interior Seaway had changed significantly after deposition of the glauconite layer. The clay also yields an abundance of plant material, fish remains, and at least one small, unidentified species of scaphitid ammonite. The specimens from WATH are similar to a specimen recovered from immediately below the Disturbed Zone at the Creighton locality (fig. 15).

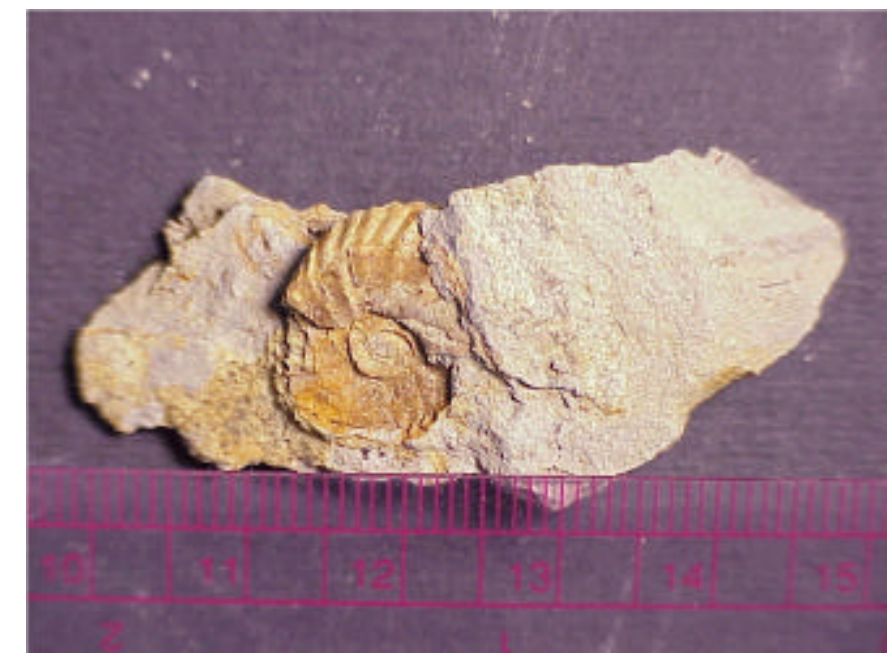

Figure 15. A scaphitid ammonite (possibly Jeletzkeytes nebrascensis) from the Disturbed Zone at the Creighton locality.

Above the red clay is the Disturbed Zone-a layer about 0.5 meters thick at this locality. Visible within figure 14 are a number of soft-sediment deformation features within this zone that we call roll-type concretions. These curved, folded, even rolled-up layers are abundant within the Disturbed Zone throughout Sec. 3, T2S, R15E. In undisturbed outcrops, all the fold axes preserve a near east-west orientation (vector mean $=270.09 \mathrm{E}, \mathrm{n}=37$ ). These structures indicate that the direction of soft-sediment movement was toward the south. At WATH, a 5 to $10 \mathrm{~cm}$ thick fine-grained sand sheet defines the base of the Disturbed Zone. The base of this sand sheet locally preserves flute casts and drag marks that indicate a strong current toward the south.

The top of the Disturbed Zone at WATH is overlain by another sand sheet preserving evidence of current movement toward the south. Above this layer are a series of alternating sand and shale layers. Fig. 14 shows fourteen such couplets in a 1.5 meter-thick section. Alternating sand and shale layers continue up-section until they gradually vanish into the deeply weathered interval in the overlying "Yellow Mounds weathering profile" (named by Pettyjohn, 1966). At the WATH locality, the distance between the Disturbed Zone and the base of the Chamberlain Pass Formation is approximately 8 meters. In the less-weathered sediment immediately above the Disturbed Zone, several varieties of trace fossils were observed including Diplocraterion, Ophiomorphia, and amphipod (sand fleas) crawling traces along with small amounts of 
glauconite (Stoffer, 1998). These fossils indicate that marine or near-marine conditions still prevailed at some point after deposition of the Disturbed Zone. The abundance of the traces listed above, particularly the amphipod traces, suggests that water depths were quite shallow (probably subtidal to lower intertidal range). After five years of field investigations, no fossils have yet been recovered from directly above the Disturbed Zone, which we interpret to represent seismically generated soft-sediment deformation and(or) tsunami deposits associated with the KT boundary.

\section{Paleomagnetic Investigation of the K-T Boundary at the WATH Locality}

Magnetic polarity data were established using a thermal paleomagnetic determination method on seven oriented samples collected from the WATH outcrop. Regrettably, many more sample determinations would be necessary to better resolve the character of the magnetostratigraphy. The following discussion examines the possible framework the data may suggest in comparison with published magnetostratigraphy determinations across the K-T boundary elsewhere. This data are still preliminary.

Magnetic normal $(\mathrm{N})$ and reversal $(\mathrm{R})$ values for tested samples are shown in figure 14 in association with a photograph taken of the outcrop site before trenching and sampling were conducted. The data, prepared by Duane Champion (a USGS paleomagnetism specialist), support the interpretation that the section in question is consistent with published data for the KT boundary (Gradstein and others, 1995; Berggren and others, 1995). A concretion tested below the glauconite layer preserves a "normal" polarity value. Considering belemnite age data, this sample would match the top of the C30n polarity. This period of normal polarity ended approximately 65.55 MA (Berggren and others, 1995). A sample from the red clam-bearing clay preserves a reverse polarity, consistent with $\mathrm{C} 29 \mathrm{r}$ that spans the K-T boundary [C29r ranges from 65.55 MA to 64.75 MA (Berggren and others, 1995)]. John Obradovich (oral commun., 1999) stated that his Western Interior data put the K-T around 65.54 MA.

According to Duane Champion (oral commun., 1999), the two oriented samples from the sand sheet at the base and at the top of the Disturbed Zone were difficult to interpret. The lower "R?" and upper "N?" bounding this zone reflect his best determination of the sample data. These samples show a mottled red to green texture. The difficulty in resolving resident paleomagnetism may be related to late diagenetic processes that overprinted the original residual magnetism.

The N, R, and R? values for the upper three samples tested have significance in resolving the nature of the section overlying the Disturbed Zone. The $\mathrm{N}$ value derived from a sample about .5 meters above the second sand sheet suggests an age value in the range of C29n-an early Paleocene (early Danian) normal polarity that lasted from $\sim 64.75 \mathrm{MA}$ to $~ 63.95 \mathrm{MA}$. The overlying R and R? values possibly correspond to C28r, an early Danian period of reversed polarity from $\sim 63.95$ to $\sim 63.65 \mathrm{MA}$.

The paleomagnetic data provide a basis for interpreting sedimentation rates for the upper part of the section. If the roughly 1 meter thick interval above the Disturbed Zone bounds the C29n polarity interval, then the sedimentation rate of this upper part of the section is roughly one meter per million years. For a rough comparison, the fully marine section between the Campanian/Maestrichtian boundary ( 71.3 MA) and the K-T boundary ( 65 MA) is roughly 40 meters thick, suggesting a sedimentation rate in the range of 6 to 6.5 meters per million years in the Pierre Shale portion of the section. This interpretation of a drastic drop in sedimentation rates across the K-T is supported by two observable characteristics of the sediments. First is that the 
clay content significantly drops above the Disturbed Zone. The silty sand sheets display an abundance of starved ripple bedding yielding amphipod tracks and Diplocraterian traces. This suggests that winnowing wave energy in a shallow marine setting prevented the overall accumulation of fines (clays), while concentrating the silt on migrating shallow sand shoals. Second is the occurrence of phosphatic concretions and nodules in the beds above the Disturbed Zone (Gordon Bell, oral commun, 1998). Phosphorite nodules precipitate extremely slowly at the expense of bone, teeth, and other organic phosphatic materials. They typically form in relatively shallow marine settings with a firm substrate.

This information supports a new interpretation of the Yellow Mounds. Pettyjohn (1966) probably named the Yellow Mounds after a series of small "yellow mounds" in Sec. 3, T2S, R15E (fig. 16). These yellow mounds rest on a hard, silica- and limonite-cemented concretionary surface that probably represents an ancient soil horizon (paleosol). This layer at the base of the yellow mounds is roughly 3 meters above the Disturbed Zone. Whereas the original marine or near-marine sediments (sand and shale) are well preserved in some localities in the outcrop area, they are completely obliterated by paleo-pedogenesis in most exposures. For sake of clarification, we cannot differentiate the original Paleocene sediments from the younger soil profile imprinted on them. This applies to park exposures, but this isn't true from the more massive, better-preserved equivalent section exposed west of Creighton. Fossils found in the overlying basal White River channel gravels of the Chamberlain Pass Fm. (Terry and Evans, 1994) that occur in association with the "Interior Red Clay" (Retallack, 1983) are dated to late Eocene.

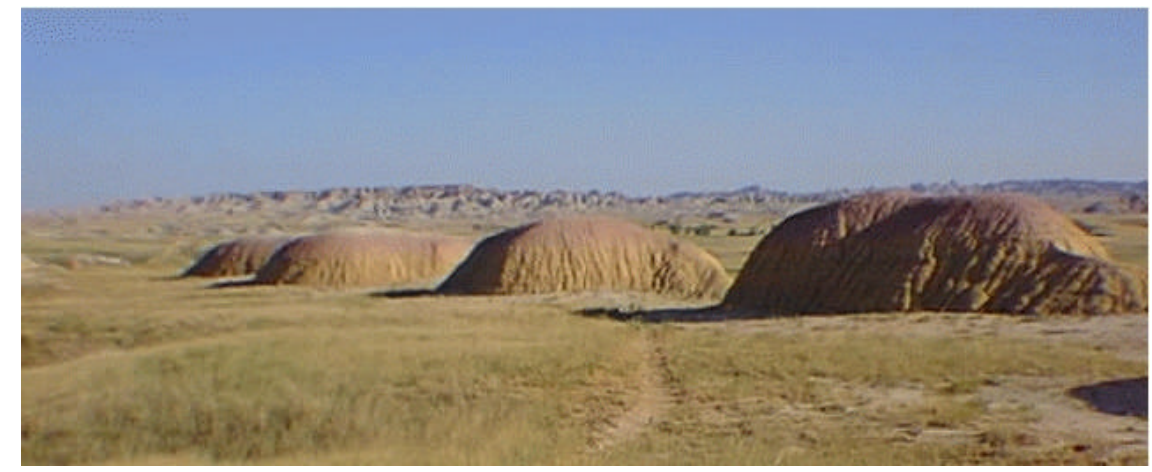

Figure 16. The "Yellow Mounds" at the WATH locality. This is perhaps the locality where Pettijohn (1966) applied the name to this interval.

\section{GRASSY TABLES OVERLOOK AREA (GTO)}

The Disturbed Zone was first reported in the area known as the Grassy Tables area of the Badlands' North Unit (Stoffer and others, 1998). The interval was interpreted as ancient slump deposits preserving an abundance of large, chaotic concretions and roll-type structures throughout the creek bed and lower hillsides along the East Fork of Sage Creek in SW, Sec. 12, T2S, R15E. The field area is in the vicinity of three brightly-colored knobs or hills, each capped with Chamberlain Pass Fm. and basal Chadron Fm. The stream cutbank in figure 17 shows a red interval that preserves chaotic bedding and roll-type concretions. These concretions occur in the Disturbed Zone throughout several hectares in this vicinity. 


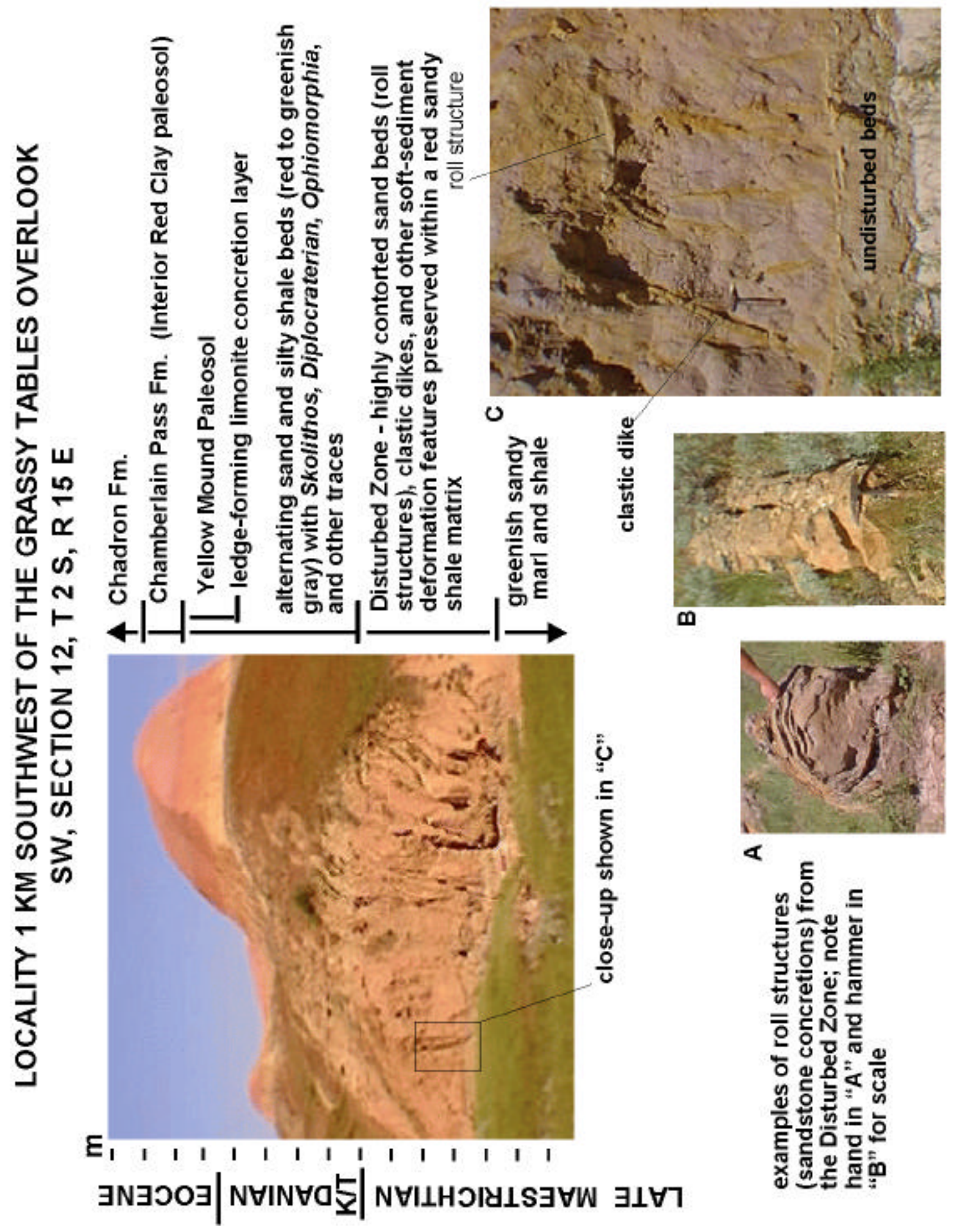

Figure 17. The Grassy Tables Overlook (GTO) locality. 
At the GTO locality, very little of the section is exposed below the Disturbed Zone. At creek level is a green, glauconitic sandy layer (probably the same as at WATH and DPCC localities). No red clam-bearing (Nucula sp.) layer has yet been observed here; it was likely eroded and incorporated into the slumped material. By comparison, the Disturbed Zone at WATH is 0.5 meters thick, whereas at GTO the interval is nearly 5 meters thick. At GTO this interval is also brightly colored (red and white) and preserves an abundance of vertically penetrating clastic dikes. This section suggests that a period of subaerial exposure occurred for long enough to allow meteoric weathering to penetrate to the bottom of the Disturbed Zone. These clastic dikes are truncated along a scoured surface overlain by greenish-drab colored alternating sand and shale identical to those at WATH. This overlying interval of alternating sand and shale sheets extends upward approximately 16 meters where its color fades into the yellowish hue typical of the Yellow Mounds paleosol. No fossils have been recovered from this locality; however, the lower sand sheets yield Ophiomorphia, Diplocraterion, and amphipod crawling traces identical to those at WATH. The sediments near the base of this section overlying the Disturbed Zone also contain some glauconite.

\section{The Paleocene/Eocene Section at the GTO Locality}

In the Grassy Tables Overlook area, the section between the top of the Disturbed Zone and the base of the Chamberlain Pass Fm. is about 16 meters thick. The section contains a thin fine-grained sand sheet between evenly bedded shale. The upper section is heavily pedogenically altered into the character of Yellow Mounds paleosols. However, changes in lithology occur in the upper part of the section below the overlying Chamberlain Pass Fm. At least one, possibly more, thin units of differing color and degree of consolidation occur in the upper part of this section. This suggests that other unconformities, or breaks in sedimentation, occurred before the White River beds were deposited. One particularly significant exposure is located at SE, Sec. 13, T2S, R15E (fig. 18). In this location, the Yellow Mounds Paleosol appears as an "orange unit" unconformably bounded below by the more tightly consolidated uppermost Fox Hills Fm. (Paleocene?), and unconformably above by poorly consolidated red clay unit (Chamberlain Pass Formation) beneath overlying white clay of the Chadron Fm. In this vicinity, the "orange unit" locally preserves migrating stream channel-style cross bedding. Whether these channels were marine or freshwater is unclear because of heavy pedogenic alteration. These unconformity bounded units are intriguing in that they suggest that sedimentary units of late Paleocene to early Eocene may have been repeatedly deposited and eroded, with small patches of these materials preserved intermittently beneath the basal White River beds (see fig. 2).

The unconformable surface between the Fox Hills alternating sand and shale interval and the "orange unit" (Yellow Mounds paleosol) possibly correlates with Haq's 58.5 million year lowstand in sea-level (Letter "E" on fig. 5). Considering the slow sedimentation rate suggested by the magnetostratigraphy data presented above, this provides a rough time-bounding estimate for the formation of the weathering profile associated the Yellow Mounds and the deposition of the overlying the red clay of the Chamberlain Pass Fm. that, based on fossils, is late Eocene. The Yellow Mounds ( "orange unit") is probably a marginal terrestrial sedimentation cycle with a heavy paleosol overprint that formed sometime in late Paleocene to early Eocene. 


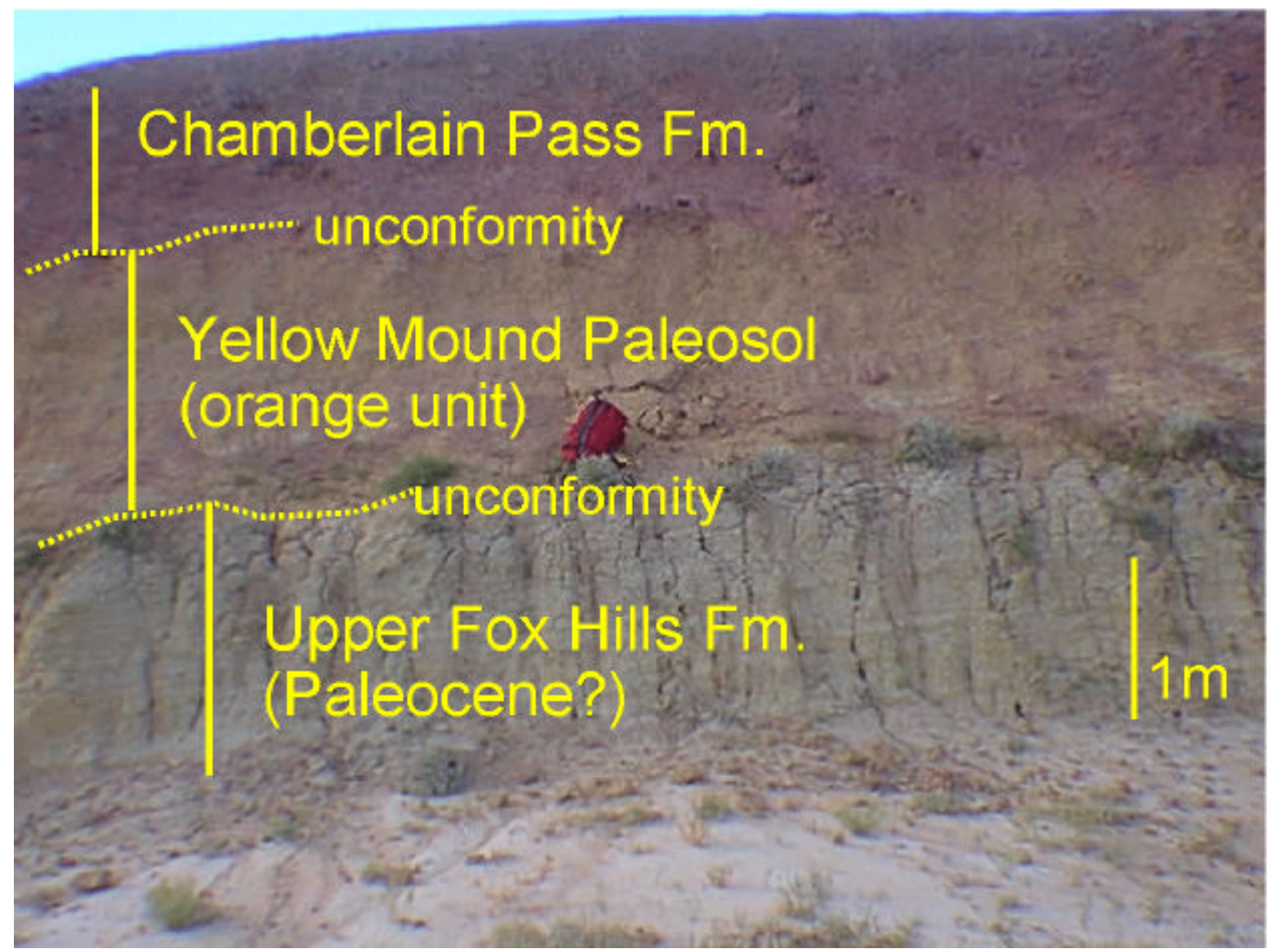

Figure 18. Three distinct lithologies (bounded by unconformities?) near the Grassy Tables Overlook locality in SE, Sec. 13, T2S, R15E.

\section{DILLON PASS/CONATA CREEK AREA (DPCC)}

The old "Rainbow Colors Overlook" along the Sage Rim Road about 1 mile northwest of the Conata Road intersection has lost its interpretive sign (fig. 19). As a result it has somewhat lost its historical significance. Its attraction is the bright yellow, orange, and red colors of the weathered strata of the Yellow Mounds. When wet, these beds stand out in stark contrast to the more mundane gray mudrock of the overlying Chadron Formation. Retallack (1985) used nearby outcrops along the headwaters of Conata Creek to describe sections for the Chadron and Brule Formations. Here Retallack (1983) recognized both "Pierre Shale" and "Fox Hills" and pondered the presence of the "Slim Buttes Formation" (an early Eocene formation in northwestern South Dakota) in the lower part of the section beneath the Chadron Formation. In this lower part of the section, he described the "Yellow Mounds Paleosol" on an irregular surface of the Fox Hills/Pierre Shale, and the "Interior Paleosol" on the surface below the Chadron Formation (on top of his "Slim Buttes Formation"). Although his interpretations are insightful, our data provide new, additional information as to the character of the Fox Hills Fm. and "Yellow Mounds." 


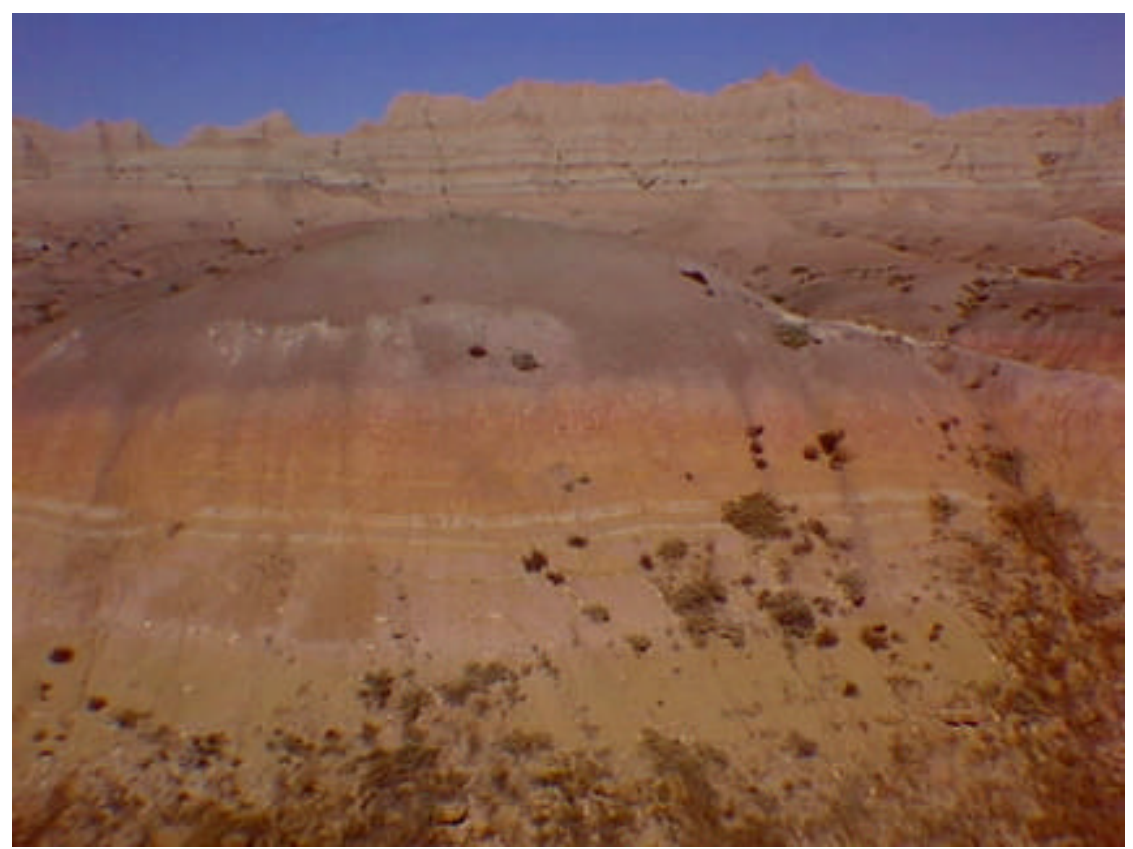

Figure 19. East view from Rainbow Colors Overlook (Sec. 21, T2S, R16E). From bottom to top: yellow=lower Fox Hills Fm.; pink=Disturbed Zone; white layers="Slim Buttes" (Retallack, 1983); orange and red=Chamberlain Pass Fm.; gray=Chadron Fm.; red and white=Brule Fm.

The K-T boundary section is perhaps best exposed in the ravines draining the High Pinnacles area along the Badlands Loop Road one mile north and west of the Conata Road intersection. This erosionally dissected area exposes the crest of the Sage Creek Anticline. The axis of the anticline trends in a northwest direction and can best be seen from the hilltop view at the Dillon Pass Overlook along the Badlands Loop Road approximately a mile east of the intersection of Conata Road. A fault on the south side of the anticline that offsets the Pierre Shale, Yellow Mounds, and White River beds is very visible along the Badlands Loop Road at the Seabed Jungle Overlook a couple hundred feet east of the Conata Road intersection. The stream bed of Conata Creek penetrates the limestone concretion-bearing shale at the base of the Elk Butte Member in the heart of the anticline. Along Conata Creek, some of the surfaces of these large unweathered limestone concretions preserve an abundance of trace fossils and fossil hash (including gastropods). In the ravine carved by Conata Creek on the west side of the Badlands Loop Road, up to 10 meters of unweathered Elk Butte shale crops out. This Elk Butte strata is overlain by brown-colored shaley strata of the lower Fox Hills Formation that bears large, heavily weathered concretions. Many of these concretions appear to have experienced exposure to alternating freshwater and saltwater conditions. All fossils and traces have been destroyed by heavy diagenetic overprints, with the ultimate result of limonite and silica generally replacing original calcareous fabrics.

Fox Hills sandstone facies are preserved only in the northwest end of the outcrop belt in the DPCC area. This northwestern part of the Fox Hills outcrop belt along the crest of the anticline is also host to several tightly cemented sand sheets (these are the Slim Buttes unit described by Retallack, 1985). Acting as water conduits in the upper part of the pre-Chadron section, these sands may have served to help protect and preserve the underlying strata from the Eocene weathering associated with the overlying red clay of the Chamberlain Pass Fm. As a result, perhaps the best K-T boundary section in the park is exposed beneath a fresh rock-fall exposure along a tributary of Conata Creek in NW, SE, Sec. 20, T2S, R16E (figs. 20 and 21). 


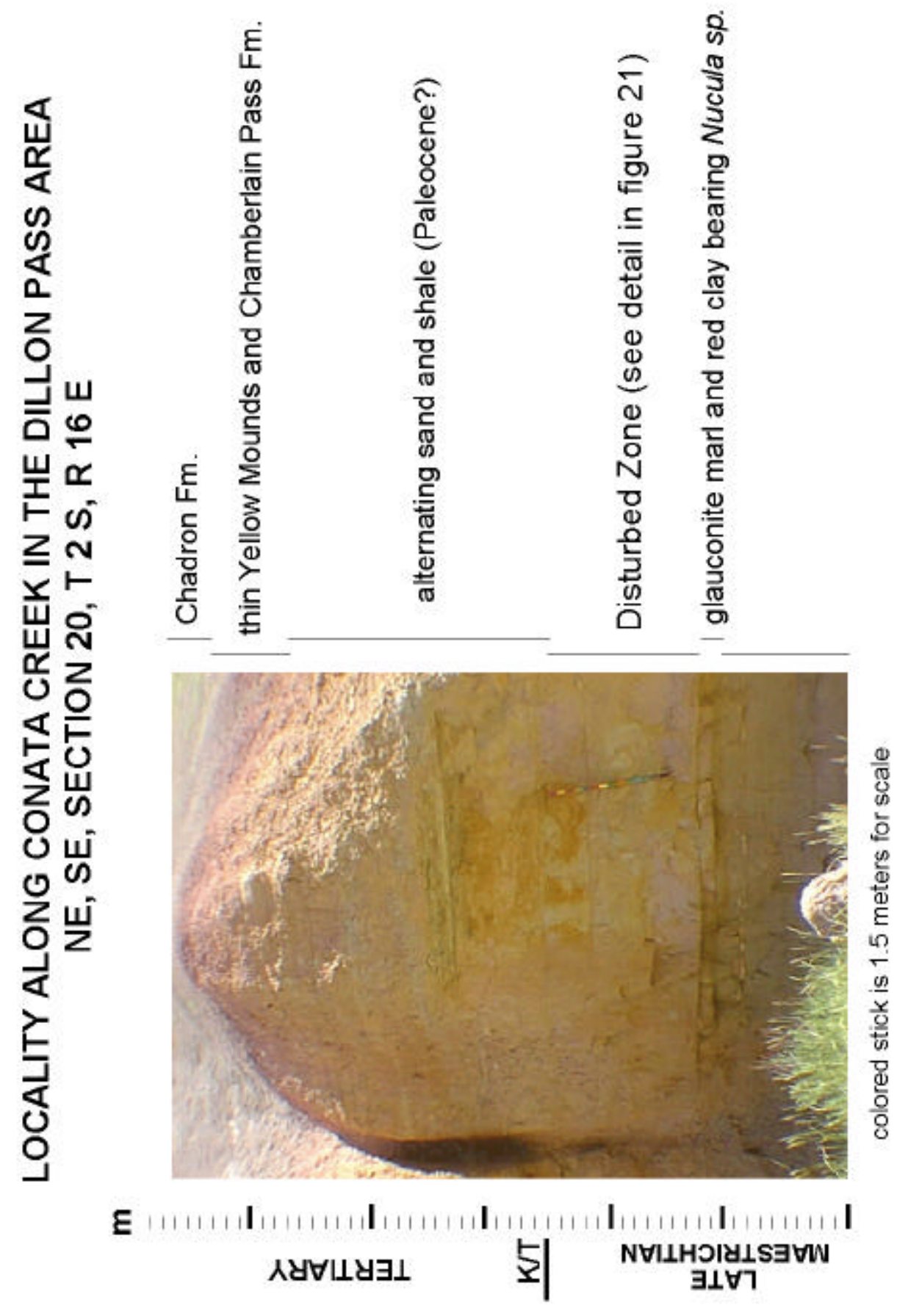

Figure 20. The Dillon Pass/Conata Creek (DPCC) locality. 


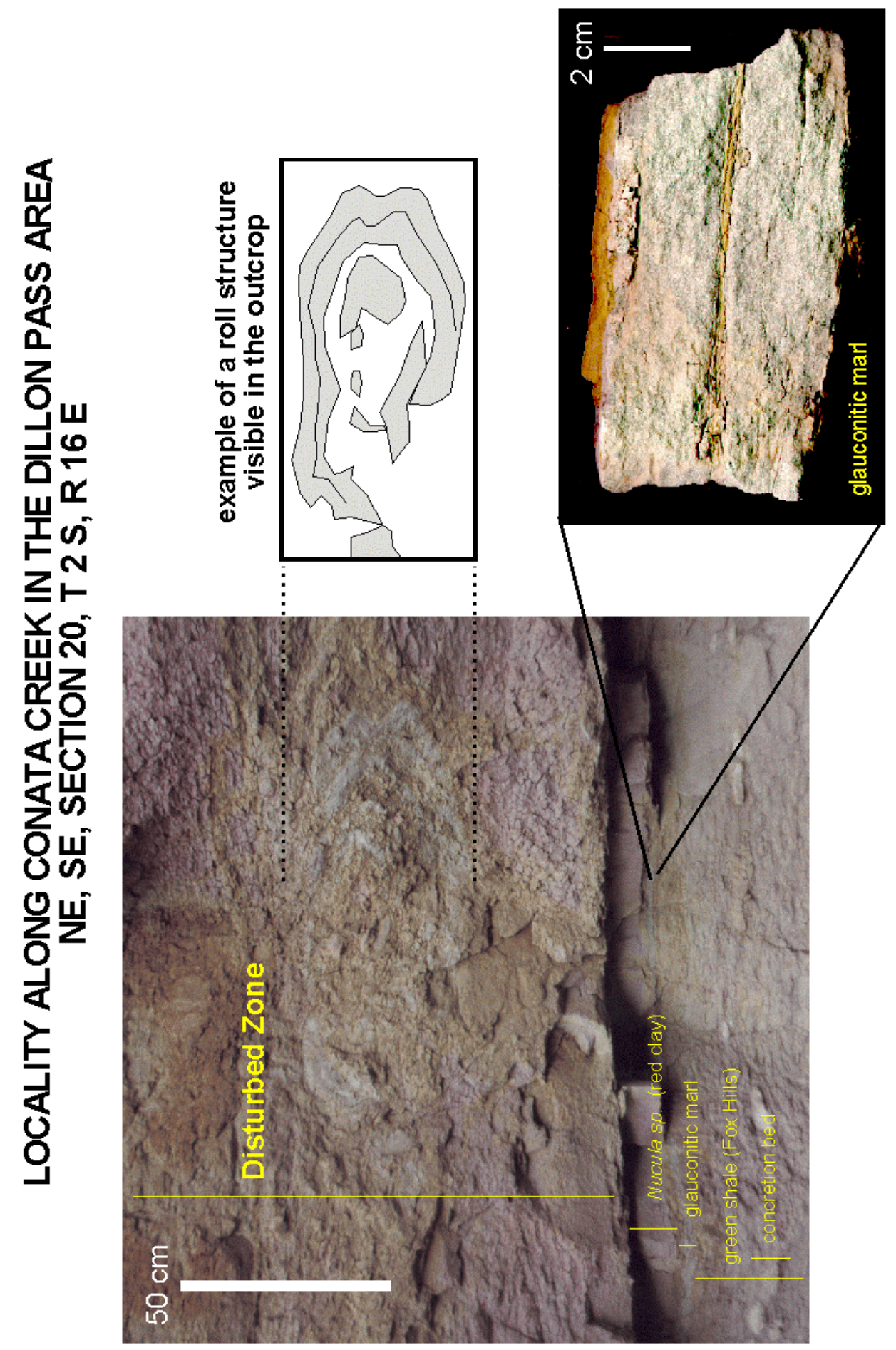

Figure 21. Close-up of the DPCC locality. 
The DPCC section shows the same basic sequence observed at the WATH locality. The DPCC stratigraphy from bottom to top follows:

1) 5.0 meters of gray to pale yellow shale of the upper Elk Butte Member,

2) 20 to 40 centimeters of a ledge-forming, brown, sandy concretion layer (a basal Fox Hills unit that crops out in Conata Creek 0.2 mile northeast of the Rainbow Colors Overlook),

3) 3 meters of dark gray green shaley marl (lower Fox Hills Fm.),

4) 10 to 20 centimeters of green glauconitic marl,

5) 20 to 30 centimeters of red clay bearing small clams (Nucula sp.) and plant material,

6) 2 meters of mudrocks preserving soft-sediment deformation (the Disturbed Zone),

7) 3 to 4 meters of alternating sand and shale (unfossiliferous upper Fox Hills),

8) 1 to 2 meters of orangish-pink, pedogenically altered shale (Yellow Mounds paleosol),

9) 0 to 2 meters of red clay (overbank deposits of the Chamberlain Pass Fm.), and

10) gray mudrock of the Chadron Fm.

A K-T boundary interval at the DPCC locality is shown in figure 20. In the vicinity of the Rainbow Colors Overlook, sand sheets above the Disturbed Zone seem to thicken or are localized along the crest of the anticline. Whether these sand sheets (Retallacks' Slim Buttes) are shoals formed on the crest of the rising anticline in the shallow seaway, or represent a localized channel formed after terrestrial exposure of the crest of the anticline in the early Tertiary remains to be resolved. However, these resistant sand sheets are important in that they seem to have served as a barrier to subsequent pedogenic alteration. They therefore preserved important stratigraphic detail in the underlying Disturbed Zone and underlying layers now exposed along Conata Creek.

The thickness and character of the exposure along Conata Creek are essentially identical to the section in the WATH locality 8 kilometers to the west and incorporate most of the characteristic units of the GTO locality 4 kilometers to the west. Considering the distance between these essentially identical exposures, this supports the plausibility that the Disturbed Zone represents the K-T boundary. It also raises significant questions about the sequence of events at the K-T transition (addressed below).

In figure 21, the bright, green glauconitic marl (5-12 cm thick) layer stands out in contrast to the strata above and below. Inspection reveals that the layer displays horizontal lamination with thin limonite-red-clay partings. The glauconite layer is unusual in that microscopic inspection shows that, in addition to a glauconite-like mineral, it is enriched in zircons, leucoxene, quartz, rock fragments, and small white carbonate clasts (2-10 mm). More information about this layer is discussed below.

The red clam-bearing layer shown in figure 21 is approximately $20 \mathrm{~cm}$ thick. Specimens of Nucula sp. clams from the WATH and DPCC localities are indistinguishable in hand samples. The overlying Disturbed Zone preserves roll-type concretions with an east-west orientation (similar to both localities described above). Fragments of concretionary material displaying rollstructure-type soft-sediment deformation are common as float in the creek beds throughout the DPCC area. This Disturbed Zone interval is 2 meters thick, displays a deep red-weathered appearance, and preserves overprint traces of Ophiomorphia. Throughout the exposure belt in the DPCC area, the Disturbed Zone interval is penetrated by numerous clastic dikes (possible 
dewatering structures). These clastic dikes are truncated by an overlying sand sheet typical of the unfossiliferous interval above the Disturbed Zone observe in the other Badlands localities.

\section{The “Glauconite Marl Layer”}

The highly unusual glauconite layer below the red clay is unlike any other rock observed in the Badlands section (see fig. 21). We believe this glauconite marl layer is extremely important in interpreting events in the K-T boundary interval. However, two working hypotheses are presented as follows. One hypothesis assumes that the origin of the glauconite layer formed via more "traditional views" of the origin of glauconite (in other words, mineralized fecal pellets deposited in sediment-starved waters during a marine transgression). A second hypothesis infers that the glauconite is a clay-mineral byproduct formed from seawater reactions with glass spherules and ash generated by an asteroid impact. In any case, the sediments and biota above and below the Badlands glauconite layer are significantly different, suggesting a major change in the overall environmental character of the Western Interior Seaway in the Badlands region, whether by transgression or by asteroid impact (or both). Additional discussion of each hypothesis follows.

\section{Hypothesis One-Biogenic Glauconite}

Glauconite has traditionally been considered an "indicator mineral" of slow, shallow marine sedimentation, particularly during periods of transgression. Glauconite occurs in abundance in marine strata in shallow shelf environments where terrestrial sediment input is reduced and sedimentation rates are extremely slow (Prothero and Schwab, 1996). Glauconite is not unusual in Late Cretaceous sediments in mid-latitude regions around the world. For instance, Late Cretaceous and Tertiary sediments of the Atlantic Coastal Plain typically preserve an abundance of glauconite, usually replacing fecal pellets or pelloidal grains with a boitryoidal form of the mineral. In New Jersey, Cretaceous, Paleocene, and younger glauconitic marls and greensands are so abundant that they are mined. Based on the sheer volume, these New Jersey glauconites are clearly of biogenic origin.

We have also observed glauconite in massive, bioturbated sandstone units in the Fox Hills Sandstone outcrops west of the Black Hills near Newcastle, Wyoming. If the Badlands glauconite is only of biological origin, then a logical interpretation is that the WATH and DPCC glauconite formed during a rapid, short-lived late Maestrichtian transgression across the Sage Creek Arch. However, the character of the immediately overlying sediments suggests that water depths were actually much shallower. If this were a transgressive-regressive cycle, it would have be rapid and different than any preceding cyclic event in the Badlands' Cretaceous section.

\section{Hypothesis Two-Asteroid Impact-Generated Glauconite}

The alternative hypothesis that the glauconite is associated with an extraterrestrial impact event warrants consideration, simply because of its implied association with K-T impact event (or events) widely discussed in the literature. The "glauconite" in Badlands is not really glauconite. X-ray diffraction analyses of the Badlands samples do not show the characteristic spectral peaks that true glauconite samples typically display. The "glauconite" is probably a suite of different clay minerals that are quite similar to glauconite in that they are enriched in Fe, $\mathrm{K}$, 
and $\mathrm{Si}$. The lack of spectral peaks in the XRD samples suggests that the original material may have been glass-like material blown from a volcanic eruption, or plausibly, an asteroid impact. In physical appearance, the glauconite layer in Badlands National Park has striking similarities to samples of a green "spherule" layer associated with the K-T Boundary reported from Ocean Drilling Program cores recovered from the offshore of the East Coast: the Blake Nose offshore from eastern Florida (Klaus and others., 2000), and the North Carolina Outer Banks (Bohor and Betterton (1989). In both Atlantic core sample localities, a green layer of similar characteristics to the Badlands glauconite layer at DPCC has been interpreted to represent an altered glass spherule layer inferred to have formed as a result of the Chicxulub asteroid impact. However, considering the location of the glauconite layer in the Badlands section, this interpretation adds confounding information to the interpretation of the K-T Boundary.

Klaus and others (2000) show images of three cores collected from the K-T boundary from the Blake Nose, a submarine high off the coast of northern Florida. The three cores preserve a green "spherule layer" 8 to $16 \mathrm{~cm}$ thick (essentially identical in appearance to fig. 21) resting on top of slumped beds they infer were K-T impact-induced mass wasting. They describe that the layers contain green spherules, shocked quartz, and clasts of limestone, dolomite, chalk, chert and schist. Similar to the Badlands glauconite layer, the Blake Nose samples are capped with a thin brown layer of limonite. The original ODP Proceedings report describes the green layer as a graded green spherule layer consisting of "altered tektites" (Norris, 1998). In these samples, as in many K-T boundary ejecta deposits, the glass has converted to "glauconite".

Bohor and Betterton (1989) presented an interpretation of another occurrence of glauconite along the K-T boundary derived from Deep Sea Drilling Project cores derived from offshore North Carolina. The complete text of their one-page paper is quoted below because it contains information that might be applied to the Badlands' outcrops. The title of the paper is Glauconite spherules and shocked quartz at the K-T boundary in DSDP Site 603 B.

\section{Bohor and Betterton (1989):}

"DSDP Site 603B, located on the lower continental rise off the coast of North Carolina, contains a 3-cm-thick layer of green clay spherules at the K-T boundary (1). This layer is crossbedded and is thought to have been transported and(or) redeposited, possibly as a turbidite. Klaver, et al. (\#1) did not find an Ir anomaly in this layer, but their analytical technique had a detection limit of only $60 \mathrm{ppb}$. INNA measurements made recently at Los Alamos show Ir values of about 0.21 in the spherule layer $(0.12 \mathrm{ppb}$ at its base) and $0.16 \mathrm{ppb}$ in the $1 \mathrm{~cm}$ of parallel-laminated sediments just above this layer.

Klaver et al. (\#1) identified the greenish clay that composes the spherules as Fe-rich smectite (nontronite). However, the high Fe and $\mathrm{K}$ content of this clay, which forms the walls of the spherules, and its color and X-ray diffraction pattern indicate a more appropriate identification as the mineral glauconite. Glauconite is often mixed with smectite in its juvenile stage. The exterior surfaces of the spherules are usually very smooth. Shapes vary from predominantly spherical (up to $1 \mathrm{~mm}$ in diameter- fig 1) to teardrops (fig 2), dumbbell, and other irregular forms. Some of the spherules are hollow, with dense glauconite walls and interior surfaces of botryoidal nontronite (fig 3); commonly the interior walls are completely filled with this nontronite. Except for composition, these spherules are similar to those found at non-marine (\#2) and other marine boundaries. We concur with the suggestion of Klaver et al. (\#1) that these spherules were originally massive and most likely consisted of glass (or a crystalline silicate). Small, solid, glauconite fecal pellets, shaped like grains of rice, also were found in this layer.

Klaver et al. (\#1) looked for shocked quartz grains in the spherule layer bud did not find any. We, however, found shocked quartz grains with multiple sets of lamillae throughout 
the spherule layer and in the $1 \mathrm{~cm}$ of laminated sediments immediately overlying it (Fig 5-6). The largest shocked quartz grain had a maximum dimension of $0.30 \mathrm{~mm}$. Because of the small amount of material examined, this size may not represent the true maximum dimension of shocked quartz at this site. We also looked for magnesioferrite in these sediments but did not find any.

The presence of shocked quartz, a subdued Ir anomaly, and the hollow spherules suggest that this layer is composed of impact ejecta from the K-T event. The lack of a large Ir anomaly and the absence of magnesioferrite indicate that most of the high-speed ejecta layer comprised of target rock and vaporized bolide, that usually overlie the spherule layer (2) is missing in this section, probably through erosion and/or redeposition. The $603 \mathrm{~B}$ site is the closest K-T marine location to North America discovered thus far. The maximu m grain distribution of shocked quartz at this site fits well with the trends exhibited in previous measurements of these grains worldwide, which indicate a North American locus for the impact (4). The hollow glauconite spherules in $603 \mathrm{~B}$ are similar to those fond at non-marine sites, which suggests that both represent original glassy forms and are not the product of terrestrial diagenesis.

References:

\#1) Klaver, GT et al, 1987. Init. Repts. DSDP Leg 93, Pt 2. p. 1039-56.

\#2) Bohor B.F., 1987. Geology 15, p. 896-899.

\#3) Bohor B. F., 1987. Earth and Planetary Science Letters, 81, 57-66.

\#4) Bohor B. F. et al., 1986. In LPSC XVII, Pt. 1, p. 68-69.”

Figure 22A shows SEM images of typical pelloidal glauconite from the Eocene Shark River Formation of New Jersey. The glauconite in New Jersey marls is highly irregular in shape (mostly botryoidal) and has a significant range in grain sizes. Many pellets preserve characteristics that clearly imply organic origin, mostly the replacement of fecal material. Figure $22 B$ shows an image of a sample from the Badlands DPCC glauconite layer. By comparison to the New Jersey glauconite, the large mineral grains in a DPCC locality sample display a highly fractured appearance and post-depositional, diagenetically altered character. Most are a uniform size of about 0.2 to $0.4 \mathrm{~mm}$. Many are hollow and are filled with calcite, suggesting that they may represent crushed and diagenetically altered glass spherules. The smaller round grain to the right (fig. 22B) looks strikingly similar to a spherule illustrated by Bohor and Betterton (1989). Elemental composition determined from energy dispersive analysis from the SEM shows that the greenish mineral (dark in image) contains $\mathrm{K}, \mathrm{Fe}$, and Si suggestive of glauconite but may possibly represent other minerals with similar elemental composition and color. Other publications that mention glauconite as a replacement or in-filling of glass spherules include Stinnesbeck and Keller (1996) and López-Oliva and Keller (1996).

Although we have not closely searched for shocked quartz in the DPCC samples, we have recovered examples of shocked quartz from samples above the Disturbed Zone from a location five miles west of Creighton, South Dakota (fig. 23), and have observed shocked quartz in samples from WATH sand sheets above the Disturbed Zone. Bohor and Betterton (1991) provide a guide for recognizing the maximum shocked-grain dimensions from $\mathrm{K} / \mathrm{T}$ ejecta in the Western Interior. Shocked quartz has been recognized in K-T boundary deposits throughout western North America. Bohor and Betterton (1991) show that the "maximum shocked grain dimension" is about $0.6 \mathrm{~mm}$ in Wyoming to about $0.4 \mathrm{~mm}$ in Alberta. Samples of shockedquartz-like grains observed from Badlands National Park range from 0.02 to $0.5 \mathrm{~mm}$. The problem is that the majority of grains in Badlands samples contain an abundance of fluid inclusions, typically along fracture lines. Whether these are truly of impact origin rather than massive explosive volcanic origin from the Cordilleran region is unclear. However, the 
"glauconite" layer is very different in appearance from the bentonite layers either in the marine beds of the Pierre Shale or overlying terrestrial units of the White River Group.

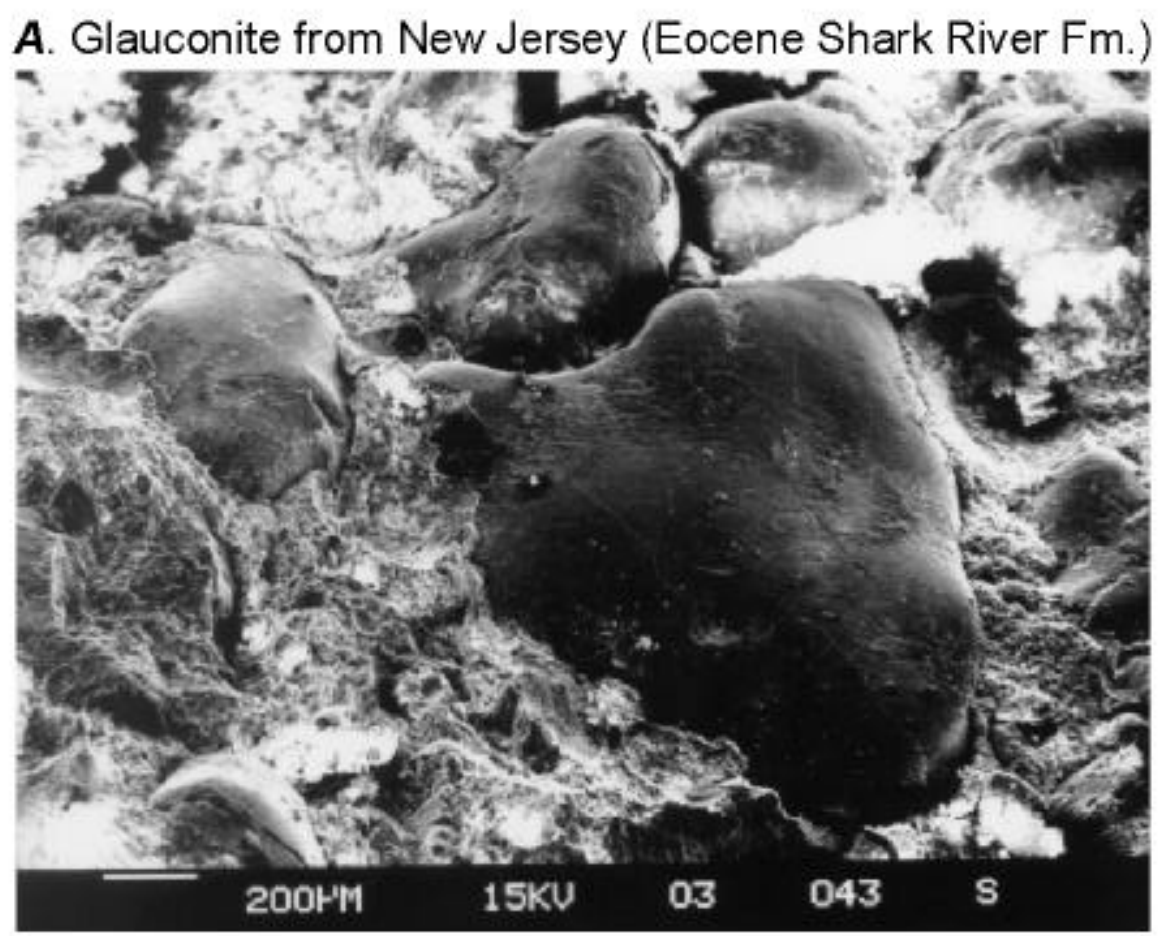

\section{B. Glauconite from Badlands National Park}

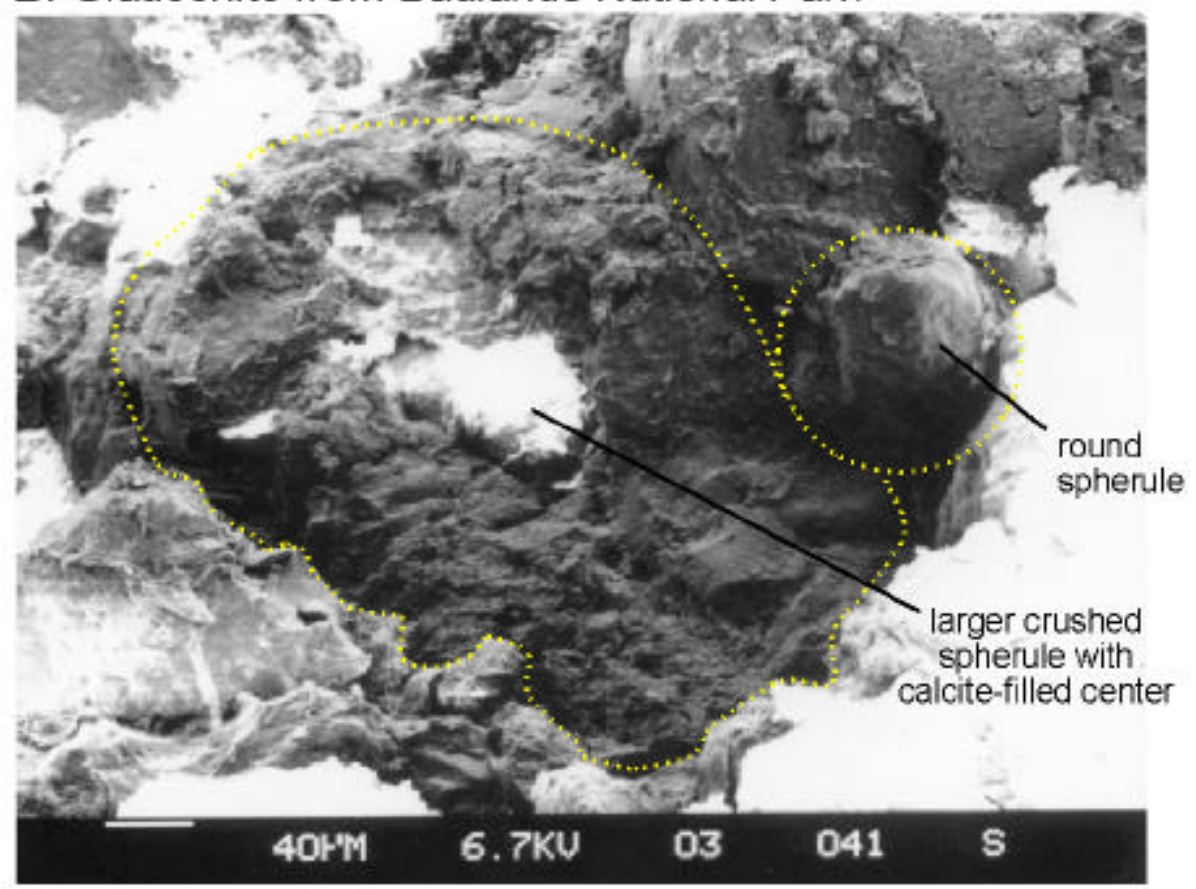

Figure 22. "Glauconite" samples under scanning electron microscopy (SEM). 


\section{$0.01 \mathrm{~mm}$}

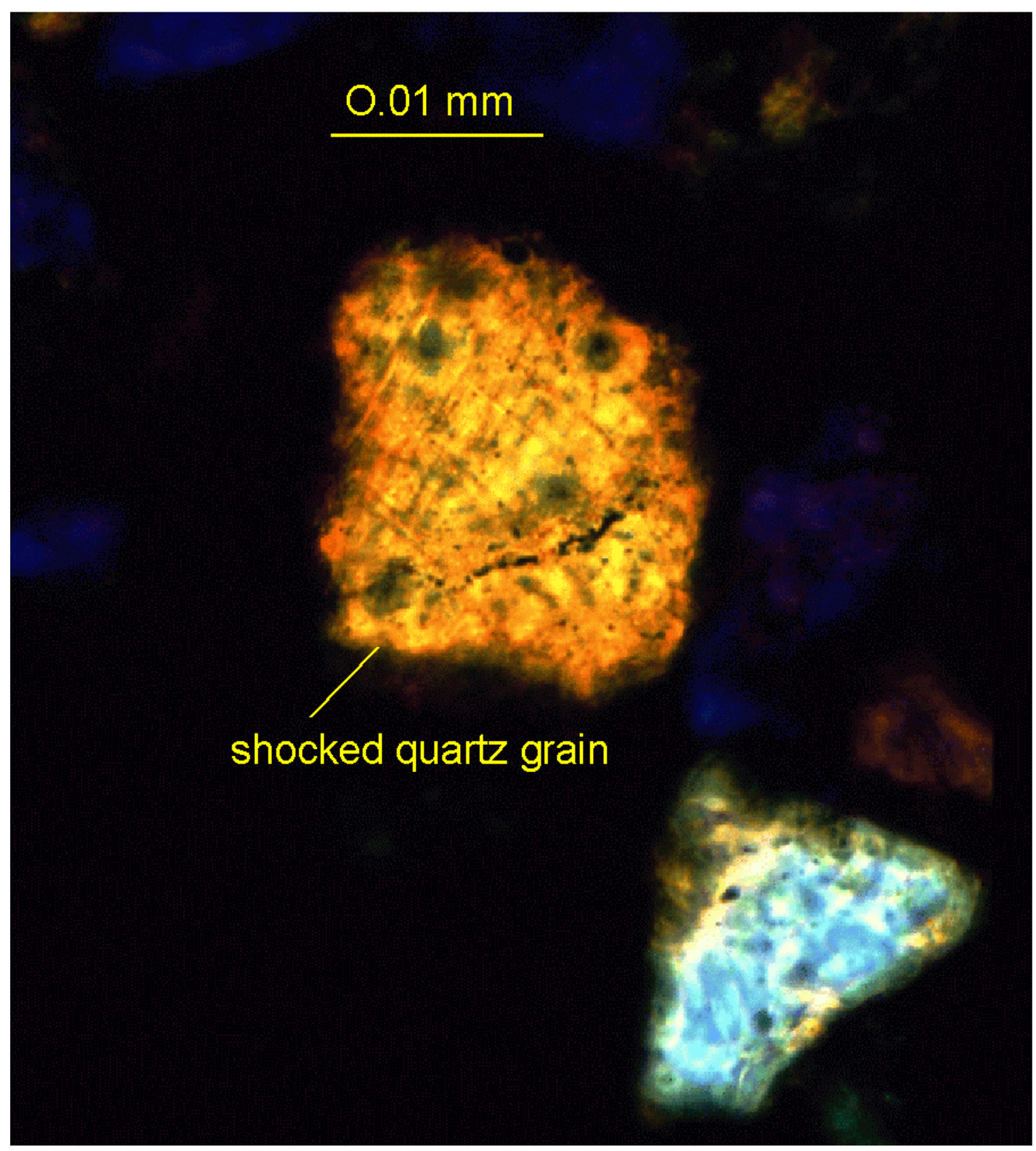

Figure 23. Shocked quartz from the Disturbed Zone from the Creighton locality (see fig. 1).

Following the assumption that the Conata Creek glauconite represents altered impact ejecta, the well-laminated character of the layer suggests that it was deposited as a gentle air fall onto the Western Interior Seaway, much in the manner that volcanic ash beds are preserved as bentonite layers in the Pierre Shale. In any case, the contrasting biologic and lithologic change across the glauconitic marl layer in the Badlands reflects a major environmental change. 


\section{THE "RED CLAY"-Changing Facies or Aftermath of an Environmental Catastrophe?}

As discussed above, the "red clam-bearing clay" conformably overlies the glauconitic marl layer. In both the WATH and DPCC localities, the red clay layer is about $20 \mathrm{~cm}$ thick (it is poorly exposed at GTO). It consists of finely laminated claystone, and contains small clams (Nucula sp.), fish remains, and carbonaceous plant material. The finely laminated clay stands out in contrast with the heavily bioturbated, belemnite-bearing strata below the glauconite layer. It is clear that environmental conditions changed drastically across the glauconitic marl layer. The occurrence of plant debris in the red clay unit is in stark contrast to the underlying Pierre Shale. It suggests either a significant slow-down in bioturbation or a reflection of a change in facies to environments closer to shore. The presence of the unidentified ammonite remains is an indication that the fauna was still "Cretaceous."

The position of the red clam-bearing layer between the glauconite bed and the overlying Disturbed Zone clearly indicates that they represent two different events. Using a conservative sedimentation rate estimate of one-meter-per-million years discussed above, the red clay bed represents a period of deposition spanning approximately 200,000 years. As Punctuated Equilibrium Theory suggests, the red clay could be a single rapid deposition event isolated in time and conditions relative to the underlying bed.

With the "transgression/regression hypothesis" the red clay might represent shallow near shore facies (because of the abundance of terrestrial plant material) immediately overlying a transgressive systems track (represented by a more traditional view of the origin of a glauconite layer). This would mean that a very rapid rise and fall in sea-level may have occurred. With the "asteroid impact hypothesis", the glauconite spherule layer represents the air fall from a distant impact. The red clay might therefore represent a "climate recovery facies", with the difference in facies and fauna being a reflection of the altered regional climate. The overlying Disturbed Zone suggests a second, possibly larger impact occurred in closer proximity, with much more catastrophic effects.

\section{THE DISTURBED ZONE—Catastrophe-Related Deposits from the Chicxulub Impact?}

Intermittently distributed slump-like bedforms occur in the same stratigraphic interval at the WATH, GTO, DPCC, and Creighton outcrops (the only locations known so far where we have seen the Disturbed Zone clearly exposed). Roll structures, chaotic bedding, and other softsediment deformation features are present in all Badlands area locations. Beds in and around the Disturbed Zone preserve striations, flute marks, and dewatering structures (some vertically penetrating holes in sand sheets look like "sand boils" that show no evidence of biogenic origin). Clastic dikes are most clearly developed in the GTO and WATH localities. The reddish to grayish purple coloration of the beds in these locations suggest that they experienced an undetermined period of subaerial exposure to meteoric water before marine sedimentation resumed (indicated by the presence of drab-colored beds bearing trace fossils immediately above the Disturbed Zone). To date, no Cretaceous fossils have either been found or reported from the beds above the Disturbed Zone. This observation must be emphasized - this interval has been the target paleontological study interval for nearly all of our investigations in the past 5 years of fieldwork. Although trace fossils, small clam fragments, and plant debris are present, no Cretaceous bone fragments or mollusks have ever been found and reported from the sediments between the Disturbed Zone and the overlying Chadron Fm. in the Badlands National Park. 
All the disrupted bedding in the Disturbed Zone shows that the direction of the mass movement was toward the south. The inclusion of the Creighton locality in the Disturbed Zone shows that its extent covers at least 300 square miles in the Badlands region. The extent of disruption may be regional if the localized "contorted bedding" interval described by Waage (1968) at the base of the Colgate Member of the type area of Fox Hills Fm. in Corson County is the same stratigraphic interval. The contorted bedding of the Disturbed Zone in the Badlands has not been observed in every outcrop where the target study interval crops out. The greatest amount of sediment disruption observed is along the crest of the Sage Creek Arch between the DPCC and WATH localities. South of the Sage Creek Arch, the Disturbed Zone features gradually fade into the more uniform tan-colored mudrocks of undifferentiated Fox Hills Fm.

Throughout the hillsides in the GTO and DPCC areas there are numerous clastic dikes penetrating through the Disturbed Zone. It is plausible that these clastic dikes are earthquakeinduced dewatering structures. They are typically filled with white, silty fine-grained mudrock that is tightly cemented by calcite. These clastic dikes are truncated by overlying drab-colored sediments bearing marine trace fossils. The dominantly east-west orientation also suggests that these are not dessication features (such as found on playas in the Desert Southwest).

The question whether the Disturbed Zone represents impact-related seismic-disturbed bedding needs embellishment. An alternative hypothesis for the origin of this deposit might be from a hurricane-like superstorm. As Hurricane Camille demonstrated in the Gulf of Mexico, hurricanes can move great volumes of shallow shelf sediments across large areas and induce submarine slumping (Morton, 1988). Criticism of the superstorm alternative are 1) why are there no other similar deposits elsewhere above and below in the stratigraphic section, and 2) why is this unique, widespread deposit observed only in close proximity to the K-T boundary? In the fossil record, storm deposits are generally very thin (measurable in centimeters). Where they occur in the rock record they typically are repeated multiple times in any particular section as a result of repeated storm events through time. In contrast, the Disturbed Zone represents a single, massive event, with deposits varying from 0.5 to $5.0 \mathrm{~m}$ in the Badlands' outcrops. The other alternative that the Disturbed Zone represents delta-front slumps has problems as well. Slumps are extremely common in modern and ancient sedimentary sequences, particularly associated with marine shelf slopes and prograding delta front sequences. However, the character and widespread distribution of the Disturbed Zone throughout the Badlands region have a unique imprint. If these deposits had formed because of typical earthquake-induced shaking, there would likely be numerous similar deposits in the section, not only in proximity to the K-T boundary. An assumption is that the Western Interior Seaway was very broad and shallow with little relief. The widespread character of the Disturbed Zone between the three Badlands localities and the Creighton locality suggest that the distribution pattern is too great for a single slump event. The stratigraphy suggests that a widespread, unique catastrophe occurred.

Tsunami deposits and impact ejecta materials are well documented at the K-T boundary in association with the Chicxulub asteroid impact. Documented localities include impact breccia and chaotic slump deposits preserved in Haiti, Jamaica, Belize, Mexico, and along the Brazos River in Texas (Hildebrand and others, 1991; Smit and others, 1996). We interpret the Disturbed Zone above the red clay to represent seismically generated deposits created by the Chicxulub impact (fig. 24). The link between the Chicxulub impact is postulated from the orientation of the roll-type concretions in the Disturbed Zone and by paleontological evidence of the late Maestrichtian fauna in the Western Interior. Kennedy and others (1998) demonstrate that most of the late Maestrichtian ammonite species have Tethyan roots. This supports the interpretation that 
the Western Interior Seaway was linked to the Gulf of Mexico at the close of the Cretaceous. At the time of the K-T impacts, the Badlands National Park area must have been situated near the eastern shore of the Western Interior Seaway. The rising uplands of the Black Hills, the Sage Creek Arch, and possibly the Chadron Arch may have served to divert the eastward flood of sediments to regions north of the Badlands area. The Badlands localities would have been in the direct path of impact-generated tsunamis that traveled northward through the seaway as slow, giant waves of transition. The seismic shaking from the asteroid impact would have begun hours before the tsunamis would have reached the South Dakota portion of the seaway and would likely have continued afterward as the massive crater continued to collapse inward.

The oriented roll-type concretions at the WATH, GTO, and DPCC localities show that sediment movement was toward the south, probably in a down-slope direction off the crest of the Sage Creek Anticline. These sediments moved as incoherent slumps or turbidity currents to their final resting places. The clastic dikes that occur throughout the GTO and DPCC localities suggest that seismic shaking created by the impact may have persisted well after the slumps had formed. These clastic dikes probably represent dewatering structures similar in character to dewatering features associated with sediment liquefaction observed in association with strong earthquakes. It is unclear whether tsunamis reached central South Dakota from the Chicxulub impact. The massive waves described in the literature affecting the Gulf Coast region would probably have largely dissipated along the extent of the Western Interior Seaway. In any case, the Western Interior Seaway experienced a rapid and enduring withdrawal for an undetermined period of time shortly after the Disturbed Zone formed. The reddish to grayish purple coloration of Disturbed Zone sediments at DPCC and especially at GTO suggests that weathering by meteoric water and subaerial exposure occurred for a significant period of time. The abundance of marine trace fossils in beds overlying the Disturbed Zone shows marine sedimentation eventually resumed. Perhaps the Western Interior Seaway may have drained catastrophically? 


\section{Paleogeography of North America at the time of the $K / T$ boundary event (about 65 million years ago)}

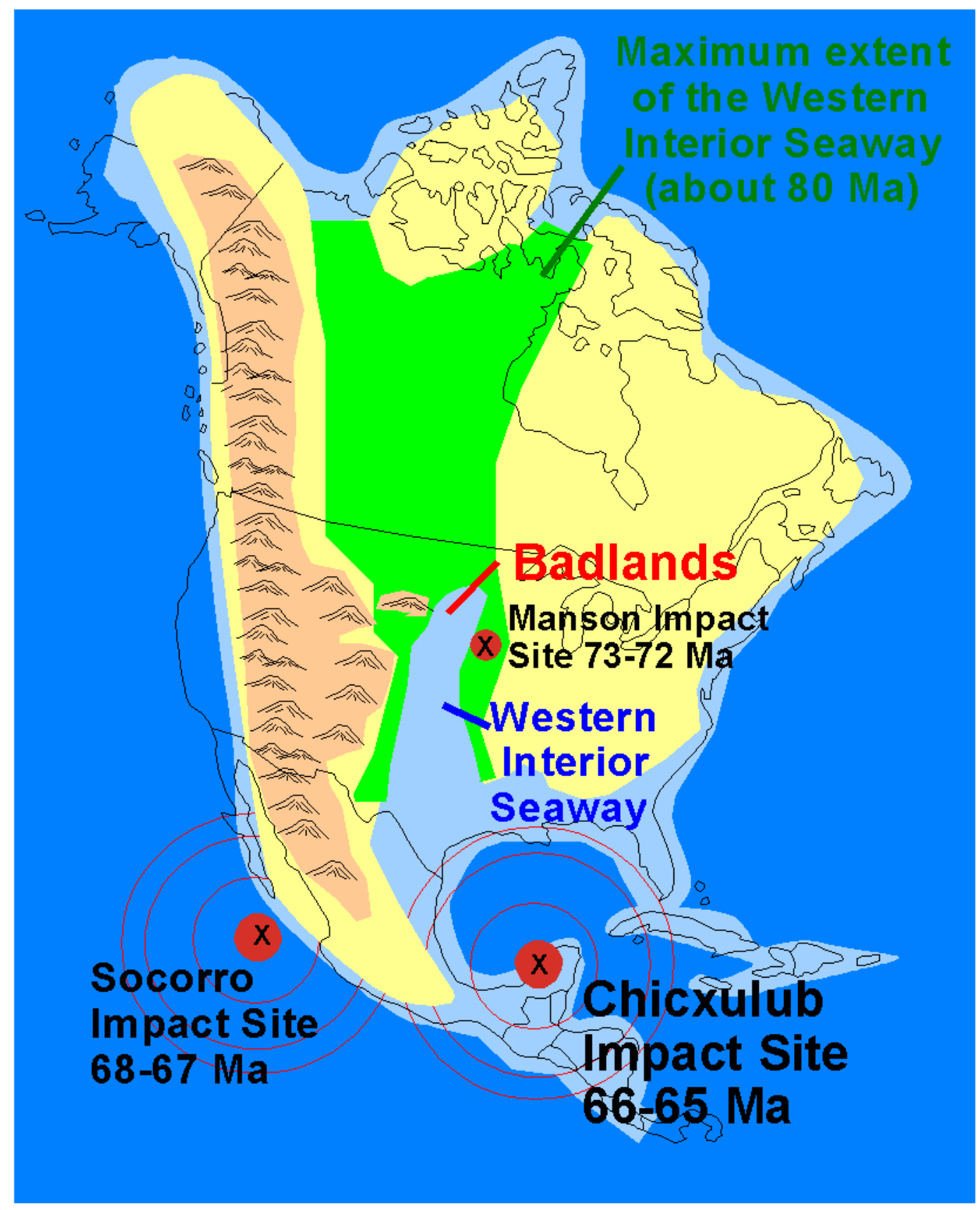

Figure 24. Paleogeography of the Western Interior Seaway during the maximum Campanian transgression to the close of the Cretaceous, plus the location of known major impact sites mentioned in this report. 


\section{Cyclic Bedding of the "Early Paleocene"-Ringing the Climate Bell?}

Considering all the evidence presented above, our assumption is that the alternating sand and shale beds overlying the Disturbed Zone are early Paleocene (Danian) in age. This interpretation is based on: (1) superposition - based on the geochronologic information and estimated sedimentation rates of the sub-Disturbed Zone section (this shows that the whole Interior Zone section is too thick not to include Paleocene age strata); (2) the variety of evidence that the Disturbed Zone is a manifestation of the K-T impact; (3) the complete lack of identifiable Cretaceous fossils above the Disturbed Zone; and (4) the paleomagnetic data from the WATH locality. Although the strata overlying the Disturbed Zone have not yielded fossils, they yield abundant evidence of marine sedimentation. The presence of Ophiomorphia, Diplocraterian, and crawling traces identical to those of modern beach "sand fleas" (amphipods) support a shallow-marine to near-shore interpretation for these beds immediately above the Disturbed Zone. The sand sheets immediately above the Disturbed Zone throughout the park appear to have been deposited on a scoured surface.

Within a meter above the Disturbed Zone all traces of glauconite are gone. This part of the section contains sand sheets averaging between 2 and $5 \mathrm{~cm}$ thick. Each sand sheet is overlain by thin shales 5 to $15 \mathrm{~cm}$ thick. As the WATH paleomagnetic data suggest, these deposits represent an overall slow sedimentation rate. The nearly uniform thickness of the alternating sand/shale beds suggests a Milankovitch-style cyclic pattern that is not obvious in the underlying Cretaceous section. This is particularly evident in the more massive Creighton outcrops where these beds are best exposed (fig. 25). Scour-type traces and parting lineations in the sand sheets suggest periods of high energy (strong currents) typical of a tidally dominated littoral setting. The reason for cyclicity for deposition of alternating sand and shale beds is unclear, but it is a persistent pattern in the section above the Disturbed Zone. As in Badlands National Park, the sediments above the Disturbed Zone at Creighton have not yielded "Cretaceous" fossils. Considering the nearly uniform thickness of the alternating sand and shale couplets, the strata suggest that a new oscillating climate pattern emerged in the Western Interior Seaway region in the aftermath of the K-T events.

\section{CONCLUDING REMARKS}

The K-T section discoveries are yet another reason Badlands National Park is worthy of its natural heritage status. These discoveries also confirm the need to support ongoing research in the park under the auspice of he NPS's natural resource protection policies. The data presented in this report suggest that the Disturbed Zone is probably the K-T boundary in marine sediments deposited in the Western Interior Seaway. Whereas the absence of fossils in the strata above the Disturbed Zone is consistent with the K-T boundary interpretation, future paleontological discoveries or geochronology data may prove that the strata above the Disturbed Zone are definitively Paleocene. With the data presented here, the Disturbed Zone clearly represents a late Maestrichtian regional environmental catastrophe with an associated intense seismic component, and is younger than the belemnite-bearing unit dated around 67.1 Ma. The differing fauna below and above a unique glauconitic marl layer suggests that a significant environmental change had already occurred a relatively short geologic time prior to the formation of the Disturbed Zone. 
The "spherule-origin hypothesis" for the glauconitic marl layer and the "seismic origin hypothesis" for the Disturbed Zone suggest that possibly two major asteroid impacts occurred near the time of the K-T transition. The occurrence of at least two impacts (one distant and one nearby; suggested names: "Alpha" and "Omega") at the close of the Cretaceous may help to explain the confusion in the literature regarding the precise geochronology of the K-T. The discovery of the K-T boundary in the Badlands section also has far-reaching implications about the paleogeography during Fox Hills time and that of the early Tertiary.

The K-T boundary inferred as the top of the Disturbed Zone marks not only a major change in biota, but also marks a major change in sedimentation patterns in the Western Interior Seaway basin. Fossil evidence from the Pierre Shale and lower Fox Hills Fm. in its type area demonstrate a diverse fauna existed up until late Maestrichtian time. However, the Badlands' sections confirms that ammonites and other Cretaceous fauna were already on their way out, but at least one species of ammonite (Jeletzkeytes nebrascensis) survived up to the final K-T event. The top of the Disturbed Zone essentially defines the chronological boundary between the end of the Western Interior Seaway and the marginal marine or non-marine facies of the Paleocene Cannonball Seaway that followed.

The discovery of K-T boundary deposits in Badlands National Park also represents an opportunity to enlighten the public about the great catastrophe at the close of the Mesozoic. The fantastic roadside exposure along the Badlands Loop Road at DPCC is perhaps the most accessible K-T Boundary outcrop anywhere on Earth, and especially in a national park, and deserves special preservation status.

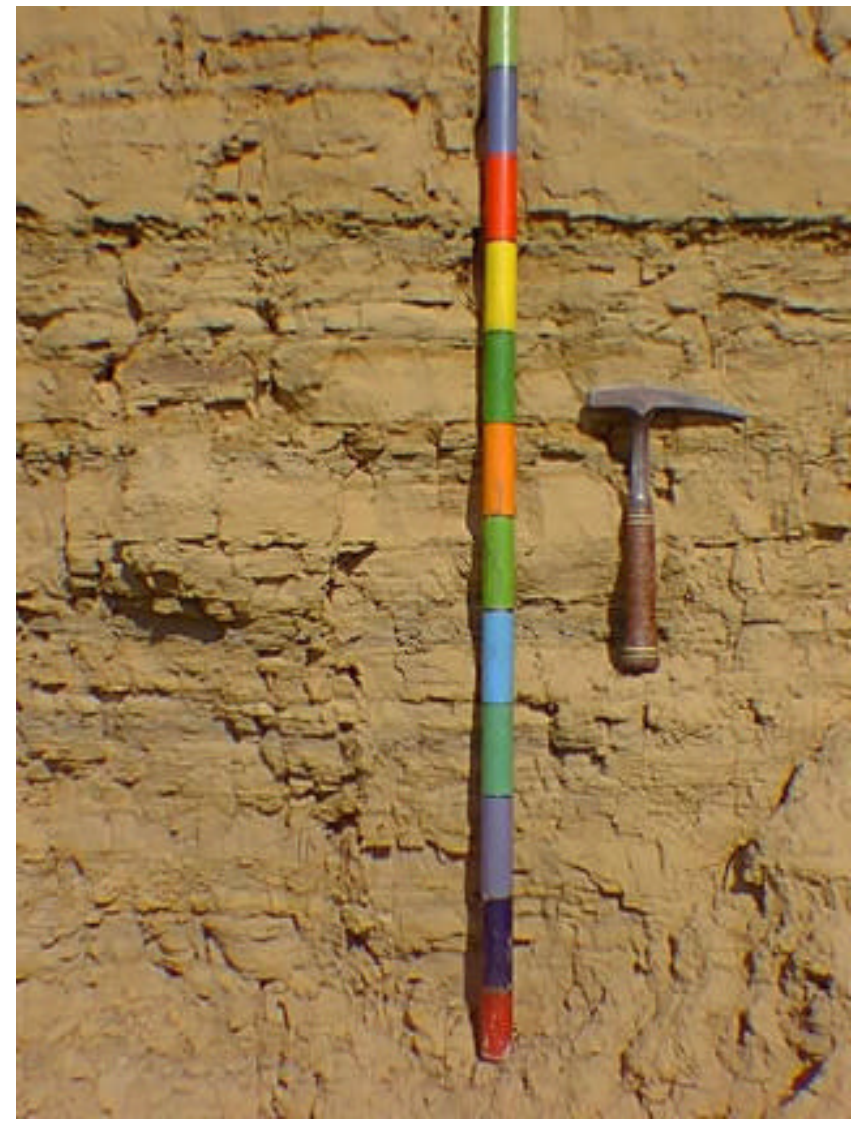

Figure 25. Cyclic bedding (sand and shale) in the fossil-barren section above the Disturbed Zone at the Creighton locality. 


\section{AUTHOR INFORMATION}

Philip Stoffer, U.S. Geological Survey, Library, 345 Middlefield Rd., MS 955, Menlo Park, CA, 94025; pstoffer@usgs.gov

Paula Messina, Dept. of Geology and Science Education Program., San José State University, San José, CA 95192-0102

John A. Chamberlain, Jr., Dept. of Geology, Brooklyn College, Brooklyn, NY 11210

Dennis O. Terry, Jr., Dept. of Geology, Temple University, Philadelphia, PA 19122

\section{SELECTED REFERENCES}

Agnew, A. F., and Tychsen, P. C., 1965, A Guide to the Stratigraphy of South Dakota: South Dakota Geological Survey Bulletin, v. 14, 195 p.

Anderson, R. R., Witzke, B. J., and Hartung J., 1996, Impact materials recoverd by Research Core Drilling in the Manson Impact Crater Structure, Iowa, in Ryder, G., Fastovsky, D., and Gartner, S., eds., The Cretaceous-Tertiary Event and Other Catastrophes in Earth History: Geological Society of America Special Paper 307, p. 527-540.

Baardsgaard, H., Lerbekmo, J. F., Wijbrans, J. R., Swisher, C. C., III, and Fanning, M., 1993, Multi-method radiometric age for a bentonite near the top of the Baculites reesidei Zone of southwestern Saskatchewan (Campanian-Maestrichtian stage boundary?): Canadian Journal of Earth Sciences, v. 30, p. 769-775.

Berggren, W. A., Kent, D. V., Swisher, C. C. III, and Aubry, M. P.,. 1995, A revised Cenozoic geochronology and chronostratigraphy. in Geochronology Time Scales and Global Stratigraphic Correlation: SEPM Special Publication no. 54, p. 129-212.

Bohor, B. F., and Betterton, W. J., 1989, Glauconite spherules and shocked quartz at the K-T boundary in DSDP Site 603 B, in Twentieth Lunar and Planetary Science Abstracts: Houston, Texas, Lunar and Planetary Science Conference, TX, v. 20, pt. 1, p. 92-93.

Bohor, B. F., and Betterton, W. J., 1991, Maximum shocked grain dimensions from K/ T ejecta, Western Interior, in Abstracts for the 54th Annual Meeting of the Meteoritical Society, Lunar and Planetary Institute: Houston, Texas, LPI Contribution 766, p. 28.

Clark, J., 1975, Controls of sedimentation and provenance of sediments in the Oligocene of the central Rocky Mountains, in Curtis, B. F., ed., Cenozoic History of the Southern Rocky Mountains: Geological Society of America Memoir 144, p. 95-117.

Crandall, D. R., 1958, Geology of the Pierre area, South Dakota. U.S. Geological Survey Professional Paper 307. 
Evans, J. E., and Terry, D. O., Jr., 1994, The Significance of Incising and Fluvial Sedimentation in the Basal White River Group (Eocene-Oligocene), Badlands of South Dakota: Sedimentary Geology, v. 90, p. 137-152.

Frye, C. I., 1964, Marine tongues in the Hell Creek Formation, North Dakota: Compass (Sigma Gamma Epsilon), v. 41, p. 167-171.

Gill, J. R., and Cobban, W. A., 1966, The Red Bird Section of the Upper Cretaceous Pierre Shale in Wyoming: U. S. Geological Survey Professional Paper 393-A.

Gill, J. R., and Cobban, W. A., 1973, Stratigraphy and Geologic History of the Montana Group and Equivalent Rocks, Montana, Wyoming, North and South Dakota: U. S. Geological Survey Professional Paper 776.

Gradstein, F. M., Agterberg, F. P., Ogg, J. G., Hardebol, J., Van Veen, P., Theirry, J., and Huang, Z., 1994, A Triassic, Jurassic, and Cretaceous time scale, in Geochronology Time Scales and Global Stratigraphic Correlation: SEPM Special Publication no. 54, p. 95-126.

Hagstrum, J., 2000, Large oceanic impacts as the cause of antipodal hotspots and global mass extinctions [abs]: Geological Society of America Abstracts with Program, v. 32, no. 6, p. 451.

Haq, B. U., Hardenbol, J., and Vail, P., 1987, Chronology of fluctuation sea-levels since the Triassic: Science, v. 235, p. 1156-1165.

Hildebrand, A. R., Penfield, G. T., Kring, D. A., Pilkington, M., Camargo, A., Jacobsen, S. B., and Boynton, W. V., 1991, Chicxulub Crater: A possible Cretaceous/Tertiary boundary impact crater on the Yucatan Peninsula, Mexico: Geology, v. 19, p. 867-871.

Kennedy, W. J., Landman, N. H., Christiansen, W. K., Cobban, W. A., and Hancock, J. M., 1998, Marine connections in North America during the late Maestrichtian: palaeogeographic and palaeobigeographic significance of Jeletzkeytes nebrascensis Zone cephalopod fauna from the Elk Butte Member of the Pierre Shale, South Dakota and NE Nebraska: Cretaceous Research, v. 19, p. 745-775.

Klaus, A., Norris, R. D., Kroon, D., and Smit, J., 2000, Impact-induced mass wasting at the K-T boundary, Blake Nose, western North Atlantic: Geology, v. 28, p. 319-322.

Koeberl, C., and Anderson R. R., 1996, Manson and Company: Impact Structures in the United States, in Koeberl, C., and Anderson R. R., eds., The Manson Impact Structure, Iowa: Anatomy of an Impact Crater: Geological Society of America Special Paper 302, p. 1-29.

Landman, N. H., and Waage, K. M., 1993, Scaphitid ammonites of the Upper Cretaceous (Maestrichtian) Fox Hills Formation in South Dakota and Wyoming: Bulletin of the American Museum of Natural History, v. 215, 257 p. 
López-Oliva, J. G., and Keller, G., 1996, Age and stratigraphy of near K-T boundary siliciclastic deposits in northeastern Mexico: Geological Society of America Special Paper 307, p. 227-242. Ludvigson, G. A., Witzke, B. J., Gonzalez, L. A., Hammond, R. H., and Plocher. O. W., 1994, Sedimentology and carbonate geochemistry of concretions from the Greenhorn marine cycle (Cenomanian-Turonian), eastern margin of the Western Interior Seaway: Geological Society of America Special Paper 287, p. 145-173.

McArthur, J. M., Kennedy, W. J., Chen, M., Thirlwall, M. F., and Gale A. S., 1994, Strontium isotope stratigraphy for Late Cretaceous time-Direct numerical calibration of the Sr isotope curve based on the US Western Interior: Palaeogeography, Palaeoclimatology, Palaeoecology, v. 108, p. 95-119.

Morton, R. A., 1988, Nearshore responses to great storms, in Clifton, H. E., ed., Sedimentologic Consequences of Convulsive Geologic Events: Geological Society of America Special Paper 229, p. 7-20.

Nelson, B. K, MacLeod, G. K., and Ward, P. D., 1991, Rapid change in strontium isotopic composition of sea water before the Cretaceous/Tertiary boundary: Nature, v. 351, p. 644-647.

Norris, R. D., Kroon, D., Klaus, A., and others, 1998, Proceedings of the Ocean Drilling Program, Initial Reports: College Station, TX, Ocean Drilling Program, v. 171B, 749 p.

Obradovich, J. D., 1993, A Cretaceous time scale, in Caldwell, W. G. E., and Kauffman, E. G., eds., Cretaceous Evolution of the Western Interior Basin of North America: Geological Association of Canada Special Paper 39, p. 379-392.

Owen, D. D., 1852, Descriptions of new and imperfectly known genera and species of organic remains, collected during the geological surveys of Wisconsin, Iowa, and Minnesota, in Report of a geological survey of Wisconsin, Iowa, and Minnesota; and incidentally of a portion of Nebraska Territory: [Philadelphia] Lippencott, p. 573-587.

Pettyjohn, W. A., 1966, Eocene paleosol in the northern Great Plains: U.S. Geological Survey Professional Paper 550-C, p. 61-65.

Pettyjohn, W. A., 1967, New members of Upper Cretaceous Fox Hills Formation in South Dakota, representing delta deposits: American Association of Petroleum Geologists Bulletin, v. 51, p. 1361-1367.

Prothero, D. R., and Schwab F., 1996, Sedimentary Geology: [New York], W. H. Freeman and Company, p. 111-112.

Raymond, W. H., and King, U. R., 1976, Geologic map of the Badlands National Park and vicinity, west-central South Dakota: U.S. Geological Survey, Miscellaneous Investigations Series Map I-934, 1 sheet, scale 1:62,000.

Retallack, G. J., 1983, Late Eocene and Oligocene paleosols from Badlands National 
Park, South Dakota: Geological Society of America Special Paper 193.

Retallack, G. J., 1985, An excursion guide to fossil soils of the mid-Tertiary sequence in Badlands National Park, South Dakota: Dakoterra, v. 2, p. 277-302.

Searight, W. V., 1937, Lithologic stratigraphy of the Pierre Formation of the Missouri Valley in South Dakota: South Dakota Geological Survey Report of Investigations no. 27.

Smit, J., Roep, T. B., Alvarez, W., Montanari, A., Claeys, P., Grajales-Nishimua, J. M., and Bermundez, J., 1996, Coarse-grained, clastic sandstone complex at the K-T boundary around the Gulf of Mexico-Deposition by tsunami induced by the Chicxulub impact? Geological Society of America Special Paper 307, p. 151-182.

Speden, I. G., 1970, The Type Fox Hills Formation, Cretaceous (Maestrichtian), South DakotaPart 2. Systematics of the Bivalvia: Yale University Peabody Museum of Natural History Bulletin no. 33, 222 p.

Stinnesbeck, W., and Keller, G., 1996, K-T boundary coarse-grained siliciclastic deposits in northeastern Mexico and northeastern Brazil—Evidence for mega-tsunami or sealevel changes? Geological Society of America Special Paper 307, p. 197-210.

Stoffer, P., 1998, Stratigraphy of the Pierre Shale and Fox Hills Fm. (Late Cretaceous) in the Badlands National Park area, South Dakota: Implications for eustacy, tectonism, and marine paleoecology of the Western Interior Seaway: City University of New York, Ph.D. dissertation, $501 \mathrm{p}$.

Stoffer, P., and Chamberlain, J. A., Jr., 1996, Unconformities in the upper Pierre Shale/Fox Hills Interval (Campanian and Maastrichtian - Late Cretaceous) in Badlands National Park area: Implications for Tectonism and Eustacy in the Western Interior Seaway [abs]: Geological Society of America Abstracts with Programs, v. 28, no. 7, p. 124.

Stoffer, P., Chamberlain, J. A., Jr., Messina, P., and Terry, D. O., 1999, Tsunamis in South Dakota? Two asteroid impacts inferred from the Cretaceous/Tertiary (K-T) Boundary Interval in Badlands National Park [abs]: Geological Society of America Abstracts with Programs, v. 31, no. 7 , p. 473.

Stoffer, P., Chamberlain, J. A., Jr., Messina, P., and Terry, D. O., 2000, K-T Boundary Stratigraphy of the Yellow Mounds in Badlands National Park, South Dakota [abs]: Geological Society of America Abstracts with Programs, v. 32, no. 7, p. 226.

Stoffer, P., Messina P., and Chamberlain, J. A., Jr., 1997, Buried slumps in the upper Pierre Shale/Fox Hills transition interval in Badlands National Park [abs]: Geological Society of America, Annual Meeting Abstracts with Programs, v. 29, no. 6, p. 274. 
Stoffer, P., Messina, P., and Chamberlain, J. A., Jr., 1998, Cretaceous stratigraphy of Badlands National Park: Implications for eustacy, tectonism, and marine paleoecology of the Western Interior Seaway: Dakotaterra, v. 5, p.55-62.

Sugarman, P. J., Miller, K. G., Bukry, D., and Feigneson, M. D., 1991, Uppermost Campanian-Maestrichtian strontium isotopic biostratigraphic, and sequence stratigraphic framework of the New Jersey Coastal Plain: GSA Bulletin, v. 107, p. 19-37.

Terry, D. O., and Evans, J. E., 1994, Pedogenesis and paleoclimatic implications of the Chamberlain Pass Formation, basal White River Group, Badlands of South Dakota: Palaeogeography, Palaeoclimatology, Palaeoecology, v.110, p.197-215.

Waage, K. M., 1968, The type Fox Hills Formation, Cretaceous (Maastrichtian), South Dakota, Part 1, Stratigraphy and Paleoenvironments: Peabody Museum Natural History Bulletin no. 27.

Ward, F., 1922, Geology of a portion of the Badlands: South Dakota Geological and Natural History Survey Bulletin, v. 11, p. 18-20.

Ward, F., 1924, The Lance problem in South Dakota: American Journal of Science, $5^{\text {th }}$ series, v. 7, p. 65-68. 